\title{
PUBLIC RESPONSE TO RACIST SPEECH: CONSIDERING THE VICTIM'S STORY $\dagger$
}

\author{
Mari J. Matsuda*
}

\section{INTRODUCTION}

$A$ black family enters a coffee shop in a small Texas town. A white man places a card on their table. The card reads, "You have just been paid a visit by the Ku Klux Klan." The family stands and leaves. ${ }^{1}$

A law student goes to her dorm and finds an anonymous message posted on the door, a caricature image of her race, with a red line slashed through it. ${ }^{2}$

A Japanese-American professor arrives in an Australian city and finds a proliferation of posters stating "Asians Out or Racial War" displayed on telephone poles. She uses her best, educated inflection in speaking with clerks and cab drivers, and decides not to complain when she is overcharged. ${ }^{3}$

$\dagger$ (c) 1989 Mari J. Matsuda. All rights reserved.

* Associate Professor of Law, University of Hawaii, the William S. Richardson School of Law. B.A. 1975, Arizona State University; J.D. 1980, University of Hawaii; LL.M. 1983, Harvard University. - Ed. The author wishes to acknowledge Hofstra University, the State University of New York at Buffalo School of Law, the University of Southern California Law Center, and the University of California at Davis, School of Law - where tentative versions of this Article were presented - and to thank Alex Aleinikoff, Monroe Freedman, Charles Jones, Amy Kastely, Charles Lawrence, Barbara Lubow, Toni Massaro, Richard Pildes, Frederick Schauer, Nadine Strossen, and René Todd for thoughtful responses to and, in some cases, disagreement with, this Article in earlier drafts. Lila Gardner, Michael Reveal, and Whitney Rup. precht provided valuable research assistance. Finally, the author owes much to Richard Delgado, whose imaginative power in responding to the problem of racism is a source of constant inspiration. To all the members of the Michigan Law Review and to the authors in this symposium issue, thanks are due for your vision and collaborative support.

1. Incidents such as this are described in P. SIMS, THE KLAN 167-72 (1978). The calling card is a typical Klan technique. Id. at 168-72; see also Vietnamese Fishermen's Assn. v. Knights of the Ku Klux Klan, 518 F. Supp. 993, 1004 (S.D. Tex. 1981) (A woman who allowed Vietnamese immigrants' fishing boats to use her docks received a card that read "You have been paid a 'friendly visit' do you want the next one to be a 'real one.' ").

2. At the University of California, Hastings College of the Law, someone defaced a Black History Month display in just such a manner. Racist Caricatures Anger Students, Recorder (San Francisco), Feb. 11, 1989, at 1. Last October, two students at Stanford University drew a racist caricature on a poster on the door of a black residential hall, and were not disciplined by the school for their actions. Id.

3. Author's personal experience, Perth, Western Australia, July 1987, recounted in Language as Violence v. Freedom of Expression: Canadian and American Perspectives on Group Defamation, 37 BufFalo L. REv. 337 (1989) (transcript of the James McCormick Mitchell Lecture, State University of New York at Buffalo School of Law, Nov. 4, 1988) [hereinafter Language as Violence]. I later learned that right-wing hate movements have been blamed for the firebombing of Chinese restaurants in Perth. Asian Immigrants Among Target of Australian Violence; Inguiry Scheduled, Pacific Citizen, Mar. 24, 1989, at 2, col. 4. 
These unheralded stories share company with the more notorious provocation of swastikas at Skokie and burning crosses on suburban lawns. ${ }^{4}$ The threat of hate groups like the Ku Klux Klan and the neoNazi skinheads goes beyond their repeated acts of illegal violence. ${ }^{5}$ Their presence and the active dissemination of racist propaganda means that citizens are denied personal security and liberty as they go about their daily lives. Professor Richard Delgado recognized the harm of racist speech in his breakthrough article, Words That Wound, ${ }^{6}$ in which he suggested a tort remedy for injury from racist words. This Article takes inspiration from Professor Delgado's position, and makes the further suggestion that formal criminal and administrative sanction - public as opposed to private prosecution - is also an appropriate response to racist speech. ${ }^{7}$

In making this suggestion, this Article moves between two stories. The first is the victim's story of the effects of racist hate messages. The second is the first amendment's story of free speech. The intent is to respect and value both stories. This bipolar discourse uses as method what many outsider intellectuals do in silence: it mediates between different ways of knowing in order to determine what is true and what is just. ${ }^{8}$

In calling for legal sanctions for racist speech, this Article rejects an absolutist first amendment position. It calls for movement of the societal response to racist speech from the private to the public realm. ${ }^{9}$ The choice of public sanction, enforced by the state, is a significant one. The kinds of injuries and harms historically left to private individuals to absorb and resist through private means is no accident. ${ }^{10}$

4. Klanwatch listed 28 reported cross-burnings in 1988. KLANWATCH INTELLIGENCE REPORT, Feb. 1989, at 11.

5. For reports of the escalating violence of hate groups, see id. See also CIVIL RIGHTS DIVISion, ANTI-Defamation League of B'NAI B'RITH, Young AND Violent: THE GRowing MeNaCe of AMERICA's Neo-NAZI Skinheads 1 (1988) [hereinafter Young and Violent].

6. Delgado, Words That Wound: A Tort Action for Racial Insults, Epithets, and Name-Calling, 17 HARV. C.R.-C.L. L. REv. 133 (1982).

7. Some state and local governments have taken steps in this direction. See infra note 138.

8. For elaboration of this point, see Matsuda, When the First Quail Calls: Multiple Consciousness as Jurisprudential Method, 11 WOMEN's RTS. L. REP. 7 (1989).

9. Lawrence Friedman has called the separation of public and private force "one of the great master trends in criminal justice." L. Friedman, A History of AMERICAN LAw 288 (2d ed. 1985). A developing state typically moves to monopolize imposition of sanctions on offensive conduct. Friedman also notes that this movement occurs when "private justice is either too ineffective or, conversely too effective, giving rise to feuds and wholesale bloodshed." Id. at 293. For a tragic illustration of private remedy, see Higgins v. Gates Rubber Co., 578 F.2d 281 (10th Cir. 1978) (An African-American employee subjected to unrelenting and long-standing racist harassment at work warned white co-workers to stop harassing him. When a white employee continued taunting, knocking off the African-American employee's hat, the African-American employee assaulted the provocateur, and was discharged.).

10. Analysis of the public-private split, suggesting its political implications, is found in femi- 
The places where the law does not go to redress harm have tended to be the places where women, children, people of color, and poor people live. ${ }^{11}$ This absence of law is itself another story with a message, perhaps unintended, about the relative value of different human lives. A legal response to racist speech is a statement that victims of racism are valued members of our polity.

The call for a formal, legal-structural response to racist speech goes against the long-standing and healthy American distrust of government power. It goes against an American tradition of tolerance that is precious in the sense of being both valuable and fragile.

Dean Lee Bollinger has concluded that a primary reason for the legal protection of hate speech is to reinforce our commitment to tolerance as a value. ${ }^{12}$ If we can shore up our commitment to free speech in the hard and public cases, like Skokie, ${ }^{13}$ perhaps we will internalize the need for tolerance and spare ourselves from regrettable error in times of stress. Given the real historical costs of state intolerance of minority views, the first amendment purpose identified by Dean Bollinger is not one lightly set aside.

Recognizing both the real harm of racist speech and the need to strengthen our dangerously fickle collective commitment to freedom of discourse, this writer intends to feel and to work within the first amendment tension armed with stories from human lives. This Article suggests in the following Part that outsider jurisprudence - jurisprudence derived from considering stories from the bottom - will help resolve the seemingly irresolvable conflicts of value and doctrine that characterize liberal thought. Part III tells the victim's story of

nist and critical literature. See, e.g., Minow, Rights for the Next Generation: A Feminist Approach to Children's Rights, 9 HARv. WOMEN's L.J. 1 (1986); Olsen, The Family and the Market, 96 HARv. L. REv. 1497 (1983); see also Williams, The Obliging Shell: An Informal Essay on Formal Equal Opportunity, 87 MICH. L. REv. 2128 (1989) (discussing the effect of privatization of remedy on racial harm).

11. DeShaney v. Winnebago County Dept. of Social Servs., 109 S.Ct. 998 (1989), denying state liability for third-party acts of child abuse, provides a recent tragic example. The historical response to racist harassment in this country has shifted with ambivalence between a public and private conception of appropriate penalties for racist speech. During the reconstruction period, several formal measures against race harassment were enacted. Subsequent enforcement was sporadic. See Hall, Political Power and Constitutional Legitimacy: The South Carolina Ku Klux Klan Trials 1871-1872, 33 EMORY L.J. 921 (1984) (discussing early federal prosecutions for race harassment). Professor Charles Jones argues for a recommitment to the thirteenth and fourteenth amendment promise of freedom through active federal prosecution for hate crimes. Jones, An Argument for Federal Protection Against Racially Motivated Crimes: 18 U.S.C. $\$ 241$ and the Thirteenth Amendment, 21 HARv. C.R.-C.L. L. REV. 689 (1986).

12. L. Bollinger, The Tolerant Society: Free SPEech and EXTremist Speech in AMERICA (1986).

13. Collin v Smith, 447 F. Supp. 676 (N.D. Ill.), affd., 578 F.2d 1197 (7th Cir.), cert. denied, 439 U.S. 916 (1978); Village of Skokie v. National Socialist Party, 51 Ill. App. 3d 279, 366 N.E.2d 347 (1977), modified, 69 Ill. 2d 605, 373 N.E.2d 21 (1978). 
the effects of racist hate speech. Part IV introduces the emerging international standard outlawing hate speech, and Part V presents the contrasting story of American first amendment jurisprudence. Part VI suggests a doctrinal accommodation of these contrasting world views, recognizing the values of liberty and equality at the heart of both the American and the international position. This part suggests a narrow restriction of racist speech, mindful of first amendment values. Part VII applies this standard to hard cases, making tentative suggestions of appropriate outcomes. Part VIII calls for doctrinal change, and concludes that an absolutist first amendment response to hate speech has the effect of perpetuating racism: Tolerance of hate speech is not tolerance borne by the community at large. Rather, it is a psychic tax imposed on those least able to pay.

\section{OUTSIDER JURISPRUDENCE}

If we cannot understand this pain that women, that Indian women, that Black women, that Hawaiian women, that Chicano women go through, we are never going to understand anything. All the mega-theory will not get us anywhere because without that of understanding, mega-theory does not mean anything, does not refiect social reality, does not reflect people's experience.

\section{- Patricia Monture 14}

There is an outsider's jurisprudence ${ }^{15}$ growing and thriving alongside mainstream jurisprudence in American law schools. The new feminist jurisprudence is a lively example of this. ${ }^{16}$ A related, and lesscelebrated, outsider jurisprudence is that belonging to people of color. ${ }^{17}$

What is it that characterizes the new jurisprudence of people of

14. Monture, Ka-Nin-Geh-Heh-Gah-E-Sa-Nonh-Yah-Gah, CLS, July 1988, at 25, 32 (Newsletter of the Conference on Critical Legal Studies).

15. This article uses "outsider" in order to avoid "minority" - a term that belies the numerical significance of the constituencies typically excluded from jurisprudential discourse. As with any attempt to classify a school of thought, this one oversimplifies and slights the nuances and diversity of a wide-ranging field.

16. See, e.g., Littleton, Equality and Feminist Legal Theory, 48 U. PITT. L. REv. 1043 (1987); Scales, The Emergence of Feminist Jurisprudence, 95 YALE L.J. 1373 (1986).

17. Examples of jurisprudential writing explicitly considering the perspective of people of color include: D. BELl, AND WE ARE NOT SAVED (1987); Crenshaw, Race, Reform, and Retrenchment: Transformation and Legitimation in Anti-Discrimination Law, 101 HARV. L. REv. 1331 (1988); Delgado, supra note 6; Hall, The Constitution and Race: A Critical Perspective, 5 N.Y.L. SCH. J. HuM. RTS. 229 (1988); Lawrence, The Id, the Ego, and Equal Protection: Reckoning with Unconscious Racism, 39 STAN. L. REV. 317 (1987); Scales-Trent, Black Women and the Constitution, 24 HARV. C.R.-C.L. L. REv. 9 (1989); Williams, Alchemical Notes: Reconstructing Ideals From Deconstructed Rights, 22 HARV. C.R.-C.L. L. REV. 401 (1987) (Patricia J. Williams) [hereinafter Alchemical Notes]; Williams, Documents of Barbarism: The Contemporary Legacy of European Racism and Colonialism in the Narrative Traditions of Federal Indian Law, 31 ARIZ. L. REv. 237 (1989) (Robert A. Williams, Jr.). 
color? First is a methodology grounded in the particulars of their social reality and experience. This method is consciously both historical and revisionist, attempting to know history from the bottom. From the fear and namelessness of the slave, ${ }^{18}$ from the broken treaties of the indigenous Americans, ${ }^{19}$ the desire to know history from the bottom has forced these scholars to sources often ignored: journals, poems, oral histories, and stories from their own experiences of life in a hierarchically arranged world. ${ }^{20}$

This methodology, which rejects presentist, androcentric, Eurocentric, and false-universalist descriptions of social phenomena, offers a unique description of law. ${ }^{21}$ The description is realist, but not necessarily nihilist. ${ }^{22}$ It accepts the standard teaching of street wisdom: law is essentially political..$^{23}$ It accepts as well the pragmatic use of law as a tool of social change, and the aspirational core of law as the human dream of peaceable existence. ${ }^{24}$ If these views seem contradictory, that is consistent with another component of jurisprudence of color: it is jurisprudence recognizing, struggling within, and utilizing contradiction, dualism, and ambiguity. ${ }^{25}$

Dean Derrick Bell's book And We Are Not Saved ${ }^{26}$ is an example of this. In a lyrical style Dean Bell describes a world infused with (1986).

18. See Lawrence, A Dream: On Discovering the Significance of Fear, 10 Nova L. REv. 627

19. See V. Deloria, Custer Died for Your Sins 28-53 (1969).

20. See Matsuda, Looking to the Bottom: Critical Legal Studies and Reparations, 22 HARV. C.R.-C.L. L. REV. 323, 344-45 (1987) (discussing alternative sources).

21. See, e.g., Donovan \& Wildman, Is the Reasonable Man Obsolete? A Critical Perspective on Self-Defense and Provocation, 14 LoY. L.A. L. REV. 435 (1981) (arguing for replacing the "reasonable man" standard used in analyzing criminal self-defense cases with a standard that recognizes the social reality of women and people of color).

22. See Jones, Article 4 of the International Convention on the Elimination of All Forms of Racial Discrimination and the First Amendment, 23 How. L.J. 429, 447-56 (1980), for an analysis of the first amendment that attempts to create a doctrinal space for the antiracist outcomes the author advocates.

23. The intuitive realism of outsiders is discussed in Matsuda, supra note 20, at 323.

24. See, e.g., Delgado, The Ethereal Scholar: Does Critical Legal Studies Have What Minorities Want?, 22 HARV. C.R.-C.L. L. REV. 301, 301 (1987) (arguing that while some aspects of the CLS approach to legal analysis are useful, its "advocacy of informality . . . ignores the need for structure in containing and eliminating racism"); Williams, Taking Rights Aggressively: The Perils and Promise of Critical Legal Theory for Peoples of Color, 5 LAW \& INEQUALITY 103 (1987) (arguing that for people of color, critical legal theory must be used to transform current injustices).

25. The theme of dualism is discussed, inter alia, in W.E.B. DuBois, THE Souls of BLACK FolK (1961), and Stetson, Introduction to BlACK SisTER: POETRY BY BLACK WOMEN, 17461980, at xviii (E. Stetson ed. 1981). See also Hall, Race and Constitution: Epilogue, N.Y.L. SCH. J. Hum. RTs. 425, 426 (1988) (A character in Hall's parable, a Mississippi grandma, says "I know firsthand the duality of law."). The duality of the Constitution has been analyzed by Justice Thurgood Marshall. Marshall, The Constitution: A Living Document, 30 How. L.J. 623 (1987).

26. D. BELL, supra note 17. 
racism. This description ties law to racism, showing that law is both a product and a promoter of racism. Like the feminists who have shown that patriarchy has had its own march through history, related to but distinct from the march of class struggle, scholars of color have shown how racism is a separate, distinct, and central phenomenon in American life.

The hopeful part of the description offered by theorists such as Bell is the occasional recognition of the vulnerability of racist structures. The few who have managed to subject the many to conditions of degradation have used a variety of devices, from genocide to liberal doublespeak, that reveal the deep contradictions and instability inherent in any organization of social life dependent upon subordination. The sorrow songs ${ }^{27}$ of the jurisprudence of color are thus tempered by an underlying descriptive message of the inevitability of humane social progress. ${ }^{28}$

This progress can lead to a just world free of existing conditions of domination. The prescriptive message of outsider jurisprudence offers signposts to guide our way there: the focus on effects. ${ }^{29}$ The need to attack the effects of racism and patriarchy in order to attack the deep, hidden, tangled roots characterizes outsider thinking about law. Outsiders thus search for what Anne Scales has called the rachet ${ }^{30}$ - legal tools that have progressive effect, defying the habit of neutral principles to entrench existing power. ${ }^{31}$ They have derived rachet-like measures to eliminate effects of oppression, including affirmative action, reparations, desegregation, and the criminalization of racist and misogynist propaganda. Such measures are best implemented through formal rules, formal procedures and formal concepts of rights, for informality and oppression are frequent fellow-travelers. ${ }^{32}$ While cogni-

27. W.E.B. DuBois used African-American "sorrow songs" - an art form reflecting the "dark past" - as headnotes to his classic text, The Souls of Black Folk See W.E.B. DuBoIs, supra note 25 , at 181 .

28. One sees in the work of Frederick Douglass, for example, this messianic belief that the best will someday come. See W. MARTIN, The Mind of Frederick Douglass 54 (1984).

29. See, e.g., Williams, supra note 10 , at 2128-30 (affirmative action and proof of discrimination; the effect and proof issue).

30. Section on Jurisprudence, Am. Assn. of L. Schs. Newsl., Dec. 1987, at 5.

31. See, e.g., Littleton, Feminist Jurisprudence: The Difference Method Makes (Book Review), 41 STAN. L. REv. 751,770 (1989) ("[T]he legal system's insistence on symmetry, even between two asymmetrically positioned social groups, keeps the door open to additional incursions of male viewpoint ....").

32. See Alchemical Notes, supra note 17, at 406-08; Delgado, Dunn, Brown, Lee \& Hubbert, Fairness and Formality: Minimizing the Risk of Prejudice in Alternative Dispute Resolution, 1985 Wis. L. Rev. 1359; $c f$. G. Allport, The Nature of Prejudice $461-78$ (1954) (discussing the effect of formal laws on personal attitudes). The use of stories, the theme of this symposium, is not necessarily a denouncement of structure in law. As I see it, stories are a means of obtaining the knowledge we need to create just legal structure. 
zant of the limits of law reform, outsider scholars have emphasized the instrumental uses of formal legal rules to achieve substantive justice.

Using the descriptive and prescriptive messages of the emerging outsider jurisprudence to confront the problem of racist hate messages provides new insights into the longstanding neutral-principle ${ }^{33}$ dilemma of liberal jurisprudence. The following section will show how the victim's story illuminates particular values and suggests particular solutions to the problem of racist hate messages.

\section{Racist Hate Messages: The Victim's Story}

The attempt to split bias from violence has been this society's most enduring rationalization.

- Patricia Williams ${ }^{34}$

\section{A. Who Sees What: Some Initial Stories}

In writing this Article I am forced to ask why the world looks so different to me from how it looks to many of the civil libertarians whom I consider my allies. Classical thought labels ad hominem analysis a logical fallacy. ${ }^{35}$ The identity of the person doing the analysis often seems to make the difference, however, in responding to racist speech. In advocating legal restriction of hate speech, I have found my most sympathetic audience in people who identify with target groups, while I have encountered incredulity, skepticism, and even hostility from others. ${ }^{36}$

33. The power of symmetry and neutrality claims is not lost on the Klan. In its efforts to exploit free speech claims it marches over the same routes as civil rights demonstrators. See, e.g., Handley v. City of Montgomery, 401 So. 2d 171 (Ala. Crim. App. 1981) (Klan attempt to march without a permit from Selma to Montgomery).

For exploration of the concepts of bias and neutrality, see Cain, Good and Bad Bias: A Comment on Feminist Theory and Judging, 61 S. CAL. L. REv. 1945 (1988), and Resnik, On the Bias: Feminist Reconsiderations of the Aspirations for Our Judges, 61 S. CAL. L. REv. 1877 (1988).

34. Williams, Spirit-Murdering the Messenger: The Discourse of Fingerpointing as the Law's Response to Racism, 42 Mrami L. REv. 127, 139 (1987).

35. See D. Walton, Arguer's Position: A Pragmatic Study of Ad Hominem ATTACK, CRITICISM, Refutation, AND FALlACY 41-42 (1985).

36. Law review articles suggesting limitation of hate speech are typically written by members of groups that have been victims of hate speech. See, e.g., Au, Freedom from Fear, 15 LiNCOLN L. REV. 45 (1984) (arguing for a revival of Beauharnais in light of increases in anti-Asian violence and propaganda); Delgado, supra note 6; Jones, supra note 22 (advocating legal response to racist speech, and recounting his own harassment - including the words, "No Blacks Allowed Here" - while a student in Wisconsin); Kretzmer, Free Speech and Racism, 8 CARDozo L. REv. 445 (1987). Feminist writers have also attempted to recognize the world view of victims of racism. See, e.g., Donovan \& Wildman, supra note 21.

In the several audiences I have addressed on this issue, women, Jews, and people of color have offered the most vocal statements of support. A notable counter example is the Jewish civil libertarians who have eloquently, and at great personal cost, argued for the free speech rights of Nazis and Klan members. This view, which sees the right of protest as essential for the protection of minorities, leads these civil libertarians to defend their enemy. See A. NEIER, DEFEND- 
This split in reaction is also evident in case studies of hate speech. The typical reaction of target-group members to an incident of racist propaganda is alarm and immediate calls for redress. ${ }^{37}$ The typical reaction of non-target-group members is to consider the incidents isolated pranks, the product of sick-but-harmless minds. ${ }^{38}$ This is in part a defensive reaction: a refusal to believe that real people, people just like us, are racists. ${ }^{39}$ This disassociation leads logically to the claim that there is no institutional or state responsibility to respond to the incident. It is not the kind of real and pervasive threat that requires the state's power to quell. ${ }^{40}$

Here are some true "just kidding" stories:

An African-American worker found himself repeatedly subjected to racist speech when he came to work. $A$ noose was hanging one day in his work area. "KKK" references were directed at him, as well as other unfortunately typical racist slurs and death threats. His employer discouraged him from calling the police, attributing the incidents to "horseplay." 41

ING MY ENEMY (1979). While I disagree with this view, I admire the courage and conviction it reflects.

37. Immediate redress is required because hate messages are rarely isolated. They usually arise in a setting where racial tensions exist, they tend to spread and replicate, and the presence of one hate message tends to give rise to others. On the university campuses, for example, it is rare to hear of one incident only. Most of the reports cited in this Article, see infra note 71, noted numerous occurrences on the same campus. In the Skokie case, anonymous anti-Semitic phone calls plagued Jewish-surnamed residents of Skokie during the controversy over the Nazi demonstrators. See Collin v. Smith, 447 F. Supp. 676, 681 (N.D. Ill.), affd., 578 F.2d 1197 (7th Cir.), cert. denied, 439 U.S. 916 (1978).

38. They Don't All Wear SheEts: A Chronology of Racist and Far Right VioLENCE — 1980-1986, at 18 (C. Lutz comp. 1987) [hereinafter THEY DON'T ALL WEAR SHEETs] (compiling thousands of racist incidents and finding that "in the overwhelming majority of instances, bigoted violence is simply ignored, dismissed as the work of young 'pranksters' or simply left unexplained"). But see CONNECTICUT Advisory CoMmirteE to tHE UNITED STATES Commission on Civil Rights, Hate Groups and ACts of Bigotry: ConNecticut's ReSPONSE 60 (Oct. 1981) [hereinafter HATE GROUPS] (eleven percent of state residents dismiss incidents as pranks). In response to NAACP and ADL testimony of firebombings and harassment in Connecticut, one local police sergeant stated: "I believe these incidents are isolated and they are not necessarily racially motivated. I think perhaps the notoriety of other communities and the publicity the news media is giving these incidents is causing some of our younger people to act in that manner." Id. at 7.

39. See Lawrence, supra note 17, at 321 (subconscious racism of ordinary people); $c f$. $\mathbf{R}$. LIFTON, THE NAZI DOCTORS (1986) (accounts of how seemingly ordinary professionals came to participate in Nazi atrocities).

40. Cf. Homant, Assessing Psychological Damages of Crime Victims, 25 TRIAL 86, 89 (1989) ("Because most people find it comforting to believe in a 'just world,' the idea that life is fair and people get what they deserve, jurors may have a natural tendency to believe victim precipitation occurred.").

41. See Citchen v. Firestone Steel Prods. Co., Nos. 12,190-EM \& 15,389-EM (Mich. Civ. Rts. Commn. May 23, 1984), reported in 1984 Michigan CIV. RTS. Commission, CASE DIGEST 13, 17-18. The Citchen case is treated extensively in Denis, Race Harassment Discrimination: $A$ Problem That Won't Go Away?, 10 Employee ReL. L.J. 415 (1984). The employee was subjected to repeated hate messages including "Get out, $\mathrm{n}-\mathrm{r}$, you ain't wanted here," "N$-\mathrm{r}$ Ben, KKK," "KKK for you, Ben." Id. at 415. Taunts included notes in his shoe, welding his 
In San Francisco, a swastika was placed near the desks of AsianAmerican and African-American inspectors in the newly integrated fire department. The official explanation for the presence of the swastika at the fire department was that it was presented several years earlier as a "joke" gift to the battalion chief, and that it was unclear why or how it ended up at the work stations of the minority employees. 42

In Jackson, Mississippi, African-American employees of Frito-Lay found their cars sprayed with "KKK" inscriptions, and were the targets of racist notes and threats. Local African Americans and Jews were concerned, but officials said the problem was attributable to children. ${ }^{43}$

An African-American FBI agent was subject to a campaign of racist taunts by white co-workers. A picture of an ape was pasted over his child's photograph, and racial slurs were used. Such incidents were called "healthy" by his supervisor. ${ }^{44}$

In Seattle, a middle-management Japanese American was disturbed by his employer's new anti-Japanese campaign. As the employer's use of slurs and racist slogans in the workplace increased, so did the employee's discomfort. His objections were viewed as overly sensitive and uncooperative. He finally quit his job, and he was denied unemployment insurance benefits because his departure was "without cause."45

In Contra Costa, California, Ku Klux Klan symbols were used to turn families looking for homes away from certain neighborhoods. The local sheriff said there was "nothing . . . to indicate this is Klan activity."46

Similarly, a Hmong family in Eureka, California, was twice victim-

locker lock, a dead mouse, fishbones, and a kerosene-soaked cross in his locker. Repeated threats over a nine-year period resulted in a diagnosis of hypertension and depression. Id. at 434-35. The Civil Rights Commission eventually awarded the employee $\$ 1.5$ million in damages. Id. at 416.

42. S.F. Fire Department Declared “Out of Control”, Asian L. Caucus Rep., July-Dec. 1987, at 1, col 1. Edwin Lee of Chinese for Affirmative Action called the swastika incident "an act of racial violence, not to be taken lightly, but to be severely disciplined." Id.

43. Poverty Law Report, Mar.-Apr. 1982, at 11, col. 2.

44. Black F.B.I. Agent's Ordeal: Meanness That Never Let Up, N.Y. Times, Jan. 25, 1988, at 1, col. 1 .

45. Complaint at 3, EEOC v. Hyster Co., Civ. No. 88-930-DA (D. Ore. filed Aug. 15, 1988) (alleging a hostile work environment created by racially objectionable advertisement campaign and use of racial slurs by management in work place). An Answer denying those allegations was filed by the defendant. See also Mr. M.K.O. v. Hyster Co., Charge No. 380,863,519, at 1-3 (Wash. EEOC Dec. 15, 1987) (determination) (The EEOC found workplace references to "J-p competition," "the J-ps are coming," "slant-eye engines," "get those J-p engines out of there," "you can't trust those J-p bastards," and noted that the local and national JapaneseAmerican community found use of racial references in the company's ad - using samurai, kabuki, sumo figures associated with competitors - offensive. The employer's Director of Human Resources testified that the word "J-p" is not derogatory. He also stated that "W-p" - an epithet directed at Italians - is not derogatory.).

Racist harassment of employees of Japanese ancestry is not uncommon. See Japanese American Library Bulletin, Winter 1989, at 4, col. 2 (noting EEOC action on behalf of Harumi Yoshimoto, targeted for "Remember Pearl Harbor" comments at a construction project).

46. Racial Violence Belies Good Life in Contra Costa County, L.A. Times, Dec. 7, 1980, at 3, col. 5 . 
ized by four-foot-high crosses burning on their lawn. Local police dismissed this as "a prank" 47

Why might anti-Japanese racial slurs mean something different to Asian and white managers? ${ }^{48}$ Here is a story of mine:

As a young child I was told never to let anyone call me a J-p. ${ }^{49} \mathrm{My}$ parents, normally peaceable and indulgent folk, told me this in the tone reserved for dead-serious warnings. Don't accept rides from strangers. Don't play with matches. Don't let anyone call you that name. In their tone they transmitted a message of danger, that the word was a dangerous one, tied to violence.

Just as I grew up to learn the facts about the unspoken danger my parents saw in the stranger in the car, I learned how they connected the violence of California lynch mobs and Hiroshima atom bombs to racist slurs against Japanese Americans.

This early training in vigilance was reinforced by what I later learned about violence ${ }^{50}$ and Asian Americans: that people with features like mine are regular victims of violence tied to a wave of anti-Asian propaganda that stretches from Boston ${ }^{51}$ to San Francisco, ${ }^{52}$ from Galveston ${ }^{53}$ to Detroit. 54

47. Asian and Pacific Islander Advisory Comm., Office of AtTorney Gen., Cal. DePt. OF Justice, FinAl Report 45 (1988) [hereinafter AtTORney General's Report].

48. Being non-Asian is not necessarily an impediment to understanding the Asian experience. Donovan \& Wildman, supra note 21 , show this in the hypothetical used in their article on provocation (arguing for reduction in the degree of criminal charge for an Asian who commits a crime under provocation of racial slurs, considering life experience of Japanese-American defendant, including World War II internment, racial harassment at work, and knowledge of prejudice against Japanese Americans).

49. This Article does not spell out racial slurs in a personal effort to avoid harm to others, and to prevent desensitization to harmful words. As Audre Lorde has written:

but I remember a promise

I made with my pen

never to leave it

lying

in somebody else's blood.

A. LoRde, To the Poet Who Happens To Be Black and the Black Poet Who Happens To Be a Woman, in OUR DEAD BEHIND Us 7 (1986).

50. Anti-Asian violence and harassment have grown considerably in recent years. See Caucus Continues Anti-Asian Violence Work, Asian L. Caucus Rep., Aug. 1988, at 2, col. 4.

51. See U.S. Commn. on Civil Rights, Recent Activities Against Citizens AND RESIDENTS OF ASIAN DESCENT (Clearinghouse Pub. No. 88, 1986) [hereinafter RECENT ACTIVITIES] (documenting hate speech and violence directed against Asians throughout the United States, including Boston).

52. See AtTORNEy General's Report, supra note 47 (documenting numerous incidents of anti-Asian violence in California).

53. See Vietnamese Fishermen's Assn. v. Knights of the Ku Klux Klan, 518 F. Supp. 993 , 1001 (S.D. Tex. 1981) (intimidation of Vietnamese fishing families by paramilitary shows of force, threats - that it "may become necessary to take laws into our own hands" and "blood blood blood" - boat rides of armed, hooded Klansmen, firing cannons, hanging effigies, threatening children and families of whites who dealt with Vietnamese, pointing weapons at Vietnamese, and threatening to burn boats at Galveston Bay, Texas). Chin).

54. See RECENT ACTIVITIES, supra note 51, at 43-44 (concerning the murder of Vincent 
The white managers who considered Mr. O. (the Japanese-American manager) an overly sensitive troublemaker, and the unemployment board that determined there was no good cause for him to quit his job, came from a different experience. They probably never heard of Vincent Chin. ${ }^{55}$ They do not know about the Southeast-AsianAmerican children spat upon and taunted as they walk home from school in Boston; about the vigilante patrols harassing Vietnamese shrimpers in Texas. 56 Nor do they know that the violence in all these cases is preceded by propaganda similar to that used in Mr. O's workplace: that those [racist slur for Asian groups] are taking over "our" country.

Stories of anti-Asian violence are regularly reported in the AsianAmerican press; 57 just as stories of synagogue vandalism are regularly reported in the Jewish-American press; ${ }^{58}$ and anti-African-American violence, including the all-too-common phenomenon of "move-in" violence, ${ }^{59}$ is regularly reported in the African-American press. ${ }^{60} \mathrm{Mem}$ -

55. Vincent Chin was a 27-year-old Chinese American beaten to death by baseball-bat-wielding thugs in Detroit. The assailants yelled, "It's because of you fucking J-ps that we're out of work!" The Vincent Chin case is a symbol to Asian Americans of the threat of racist violence. See Civil Rights Capacity-Building Project, asian American Resource Workshop, To LIVE IN PEACE . . . Responding to ANTI-Asian Violence IN Boston 8 (1987).

56. See id. at 9-16 (citing several murders, beatings, fire bombings and harassment of Asians in the greater Boston area, including spitting and pebble-throwing directed against Cambodian school children); Vietnamese Fishermen, 518 F. Supp. at 1001.

57. See, e.g., Chin, Violence Against Asians, RiCE, Feb. 1988, at 72; Compilation of Racial Attacks on [Asian] Indians, APAC Alert, Nov. 1988, at 1, col. 1 (newsletter of the Asian Pacific American Coalition, U.S.A); Dangerous Upsurge in Immigrant Scapegoating, CAAV Voice, Fall 1988, at 3, col. 2 (newsletter of the Committeee Against Anti-Asian Violence); Caucus Continues Anti-Asian Violence Work, Asian L. Caucus Rep., Aug. 1988, at 2, col. 2. Anti-Asian violence is regularly reported in the Pacific Citizen, a weekly newspaper published by the Japanese American Citizens League.

58. See, e.g., The Jewish Journal of Greater Los Angeles, for articles on hate crime, including Noonan, Locking Out Crime, Jewish J. of Greater L.A., Feb. 24-Mar. 2, 1989, at 5, col. 1; Pfefferman, Hate Crimes' Victims, id. at 5 (There are reports of vandalism every three weeks at Temple Beth Torah in Ventura - including graffiti, a dead pig carcass, break-ins, rocks thrown, shotgun blasts, and broken windows and doors. The President of the congregation reported "I'm not dealing with it well. I just feel so violated."); Carroll, Former Klansman's Election, id. at 6; Levin, Trouble on the Campus, id. at 7. See also Simon Wiesenthal CENTER, Response, Aug. 1988, at 6 (reporting synagogue arson).

59. See, e.g., Mich. Advisory Comm. to the U.S. Commn. on Civil Rights, Hate Groups in Michigan: A Sham or a Shame 5-6 (1982) (reporting a black woman's loss of four fingers in a pipe-bomb explosion in her home in a predominantly white neighborhood in Detroit; "KKK," "White Power" and racial epithets spray-painted on a church after a black congregation moved into the facility located in a predominantly white neighborhood in Detroit); For the Record, Klanwatch Intelligence Report, May-June 1987, at 8, col. 1 (reporting numerous incidents of move-in harassment and violence); Now Is the Time: Outlaw the KKK, Nazis, and Other Hate Groups, The Organizer, June/July 1986, at 2, col. 1, at 7, col. 2 (newsletter of the National Alliance Against Racist \& Political Repression ("NAARPR")) (The house of a black couple was firebombed the night they moved into a white neighborhood in suburban Louisville, Kentucky. Several members of the police force at the time of the incident were members of the KKK. The KKK had also invaded a meeting of the NAARPR in Louisville.). 
bers of target-group communities tend to know that racial violence and harassment is widespread, common, and life-threatening; that "the youngsters who paint a swastika today may throw a bomb tomorrow."61

The mainstream press often ignores these stories, giving rise to the view of racist and anti-Semitic incidents as random and isolated, and the corollary that isolated incidents are inconsequential. ${ }^{62}$ For informed members of these victim communities, however, it is logical to link together several thousand real life stories ${ }^{63}$ into one tale of caution. ${ }^{64}$

\section{B. The Structure of Racism}

While this Article focuses on the phenomenology of racism, it includes discussion of the closely related phenomenon of anti-Semitism. The same groups, using many of the same techniques, and operating from many of the same motivations and dysfunctions typically produce racist and anti-Semitic speech. The serious problems of violent pornography and anti-gay and anti-lesbian hate speech are not discussed in this Article. ${ }^{65}$ While I believe these forms of hate speech

60. See, e.g., The NAACP 1988 Convention Resolutions, THE CRISIS, Dec. 1988, at 27, 28 (reporting NAACP convention resolution on racially motivated violence, citing incidents in Ohio, Indiana, Georgia, New York, Alabama, New Jersey, and at the University of Michigan and the University of Massachusetts at Amherst).

61. Ga. State Advisory Comm. to the U.S. Commn. on Civil Rights, Perceptions of HATE Group ACTIVITY IN Georgia 3 (1982) [hereinafter HATE Group ACTIVITY] (testimony of Stuart Lowengrub, Southeastern Regional Director, Anti-Defamation League of B'nai B'rith, Atlanta).

At the University of Maryland, two-thirds of the white students had not heard of racist incidents, while four-fifths of African-American students had. Wilkerson, Campus Blacks Feel Racism's Nuances, N.Y. Times, Apr. 17, 1988, at 1, col. 3, at 34, col. 4.

62. For two constrasting views of how courts perceive these "isolated incidents," compare Blanco v. Hallmark Cards, 681 F. Supp. 692 (D. Kan. 1987) (occasional epithets do not create a hostile work environment), with Kunz v. New York, 340 U.S. 290, 295 (1951) (Jackson, J., dissenting) (recognizing the abusive nature of epithets).

63. See They DoN'T ALL WeAR SheETs, supra note 38 (3000 acts of bigoted violence reported from 1980-1986). One study found that one out of four or five minority persons is victimized by hate activity in the course of a year. Bigots' Crimes Called More Violent Than Perceived, Chicago Tribune, Mar. 28, 1989, at 3, col. 2 [hereinafter Bigots' Crimes] (reporting findings of the National Institute Against Prejudice and Violence).

64. The Klan has admitted in court documents that its goal is to interfere with the exercise of civil rights, and that it accomplishes this by assaults, threats, and harassment against African Americans and against whites who support civil rights. This admitted purpose and method is what makes the word "KKK" and Klan symbolism so threatening to targets. See United States v. Original Knights of Ku Klux Klan, 250 F. Supp. 330, 337 (E.D. La. 1965) (reporting Klan admissions and explaining that they were made in order to prevent the taking of evidence from over 100 government witnesses on the goals and intimidation tactics of the Klan).

65. See American Booksellers Assn. v. Hudnut, 598 F. Supp. 1316 (S.D. Ind. 1984), affd., 771 F.2d 323 (7th Cir. 1985), affd. mem., 475 U.S. 1001 (1986) (declaring unconstitutional an attempt to ban pornography that subjugates women); Brest \& Vandenberg, Politics, Feminism, 
require public restriction, these forms also require a separate analysis because of the complex and violent nature of gender subordination, and the different way in which sex operates as a locus of oppression. ${ }^{66}$ They are, therefore, beyond the scope of this piece.

The claim that a legal response to racist speech is required stems from a recognition of the structural reality of racism in America. Racism, as used here, comprises the ideology of racial supremacy and the mechanisms for keeping selected victim groups in subordinated positions. ${ }^{67}$ The implements of racism include: 68

1. Violence and genocide;

2. Racial hate messages, disparagement, and threats;

3. Overt disparate treatment; and

4. Covert disparate treatment and sanitized racist comments.

In addition to physical violence, there is the violence of the word. ${ }^{69}$ Racist hate messages, threats, slurs, epithets, and disparagement all hit the gut of those in the target group. The spoken message of hatred and inferiority is conveyed on the street, in schoolyards, in popular culture and in the propaganda of hate widely distributed in this country. ${ }^{70}$ Our college campuses have seen an epidemic of racist incidents

and the Constitution: The Anti-Pornography Movement in Minneapolis, 39 STAN. L. REV. 607 (1987).

66. Violence and hate speech directed against women, gays, and lesbians, for example, are commonplace, socially accepted, and widely distributed across lines of race, class, and geography. Pornography affects women through different mechanisms than does hate speech. Pornography is the direct portrayal of sexual use and abuse of women, tied to the practice of actual violence. The visceral, "noncognitive," and violent nature of pornography is central to calls for its restraint. See, e.g., Dworkin, Against the Male Flood: Censorship, Pornography, and Equality, 8 HARV. WOMEN's L.J. 1 (1985) (discussing, inter alia, pornographic portrayal of women being killed and mutilated, and the direct connection between pornography and violence); Sunstein, Pornography and the First Amendment, 1986 DukE L.J. 589.

67. For a review of definitions of racism, see W. SEDlACEK \& G. BRooks, RACISM IN AMERICAN Education: A MODEl For CHANGe 38 (1976). Racism includes conscious as well as unconscious acts of subordination; thus no claim of intentionality is made in this Article. See Lawrence, supra note 17.

68. H. KitaNo, Race Relations 121-29 (1974) (discussing stages of ethnic identity); H. Schuman, C. STeEH \& L. Bobo, Racial AtTitudes IN AMERICA 193-212 (1985) (changing methods of expressing racist views).

69. Cf. Cover, Violence and the Word, 95 YALE L.J. 1601 (1986) (noting that the process of interpretation of legal language is ultimately bound to the imposition of violence).

70. The rise in hate crimes by minors is sad testimony to the spread of the racist message. Uzelac, Punk-Rocking, Neo-Nazi 'Skinheads' Giving Boost to Hate Groups, Atlanta J. \& Const., Jan. 2, 1989, at A2, col. 6 (Seventy children gathered at a Mississippi training camp in December 1988 for white supremacist political education and military drills. For target practice they reportedly shot at images of Dr. Martin Luther King, Jr.). In Davis, California, Thong Hy Huynh, a Vietnamese-American high school student was stabbed to death after months of racial taunts. A memorial marking his death was spray-painted with swastikas and "Death to G-ks." ATTORNEY GENERAL'S REPORT, supra note 47 , at 44.

The influence of hate propaganda on psychopathic killers also reveals the widespread availability of the culture of hate. See ATTORNEY GENERAL's REPORT, supra note 47, at 44 (pregnant Chinese immigrant pushed in front of oncoming subway train by man who feared Asians); $A$ Law 
in the 1980s. ${ }^{71}$ The hate speech flaring up in our midst includes insulting nouns for racial groups, degrading caricatures, threats of violence, and literature portraying Jews and people of color as animal-like and requiring extermination..$^{72}$

for Racist Killers, NEwSwEEK, Feb. 23, 1981, at 80 (schizophrenic killer thought African Americans were "like animals, to be eaten."); Social Worker Relates Stockton Tragedy to JACL National Board, Pacific Citizen, Feb. 10, 1989, at 1, col. 1 (mass murder of Southeast AsianAmerican school children by deranged killer with possible racial motivation).

71. See They Don't All Wear Sheets, supra note 38, at 12 (noting increase of racist incidents on college campuses); Lord, Greek Rites of Exclusion, 245 NATION, 10 (1987) at 10 (At the University of Michigan: racist leaflets in dorms, verbal abuse of African-American students, white students painting themselves black and placing rings in their noses at "jungle parties"); White, The New Racists, Ms., Oct. 1987 at 68 (reporting racist incidents at the University of Michigan, the University of Massachusetts at Amherst, the University of Wisconsin, the University of New Mexico, Columbia, Wellesley, Duke, and UCLA); Wilkerson, supra note 61 (reporting fliers urging lynchings, epithets, stone-throwing, swastikas, and anti-Asian graffiti, at several American universities); Cohen, White Supremacists Find Recruits on Campus, Klanwatch Intelligence Report, Feb. 1988, at 15, col. 1 (flyers stating "The Knights of the Ku Klux Klan are watching you" distributed at Northwest Missouri State University; KKK members speaking at Kansas University; White Student Union formed at Temple University; White Student Union flyers at University of Wisconsin, Milwaukee; Aryan Resistance literature at Stanford; Invisible Empire literature at Stockton State College, New Jersey; bomb threats at Memphis State University Jewish Student Union; bullet fired at Hillel Foundation Building at Arizona State University); Roses and Thorns, Perspectives (American Historical Association Newsletter), Sept. 1987, at 23 (statement of historians attending the Fifth Citadel Conference on the South, expressing "concern over continued racial incidents upon the nation's campuses" and noting intimidation of African-American students at Harvard, Rutgers, Purdue, Columbia, the Citadel, and the Universities of Massachusetts at Amherst, Michigan, and Wisconsin); see also Wiener, Reagan's Children, Racial Hatred on Campus, 248 NATION, 260 (1989) (Racist statements and incidents at the University of Michigan, Dartmouth, Wisconsin, UCLA, Purdue, Montclair State College, New Jersey were reported. At Michigan, a campus radio announcer referred to African hair as "pubic" hair. At Dartmouth, a professor was called "a cross between a welfare queen and a bathroom attendant," and the Dartmouth Review purported to quote a black student, "Dese boys be sayin' that we be comin' here to Dartmut an' not takin' the classics. You know, Homa ...." At Wisconsin, a fraternity held a mock "slave auction" and other fraternities held black-face "Harlem parties," and used anti-Semitic remarks. At Purdue, a counselor found "Death N-r" scratched on her door); Racist Caricatures Anger Students, supra note 2; Cal Poly Pomona Students Protest Anti-Asian Attacks, Pacific Citizen, Mar. 17, 1989, at 1, col. 4 (students protest racist incidents including attack on a Japanese-American woman); Harvard Law Record, Jan. 20,1989 , at 8, col. 1 (burning and ripping of Jesse Jackson poster, swastika in elevator, defacing of women of color poster, placing a laundry ticket on Asian students poster, reported at NYU Law School); Harris, Hindman's "Nega" Example Reveals Problem, Cavalier Daily (University of Virgina), Nov. 10, 1988, at 2, col. 2 (A student's comments on the events surrounding, and following, an incident involving Phi Gamma Delta fraternity party fliers using words "No... short $w-p s$ and please no nega babes." Fraternity members reported these were inside jokes intended to insult women and were not of a racial nature. Several weeks later, the student found a sign repeating the slur. The sign had been posted by a vice chairman of the Honor Committee.); Klanwatch Intelligence Report, Feb. 1988, at 13, col. 1 ("KKK" carved on dormitory room door of two African-American women students at Chapel Hill, North Carolina); id. at 18, col. 2 (Social Nationalist Aryan People's Party literature distributed at Mills College; anti-Semitic flyers at Stanford prior to the 50th anniversary of Kristallnacht); Professor Fasts to Right Violence Against Asians, Pacific Citizen, Sept. 9, 1988, at 1, col. 1 (Asian-American students at the University of Connecticut at Storrs were harassed and spat upon. A Chinese-American professor began a hunger strike in protest.).

72. For a case involving victims of such speech, see, e.g., Cummings v. Adkins, No. 79-202278-0 (Yakima, Wash., County Super. Ct. Aug 10, 1981), described in 25 ATLA L. Rep. 66 (1982) (employee subject to racial slurs at work). For a horror story of racial harassment in the workplace, see Taylor v. Jones, 653 F.2d 1193, 1198-99 (8th Cir. 1981) (African-American Ar- 
While violence and hate propaganda are officially renounced by elites, ${ }^{73}$ other forms of racism are not. ${ }^{74} \mathrm{Jim}$ Crow, which persists today in the form of private clubs and de facto segregated schools and neighborhoods, is seen as less offensive than cross burnings. Covert disparate treatment and sanitized racist comments are commonplace and socially acceptable in many settings. ${ }^{75}$ The various implements of racism find their way into the hands of different dominant-group members. Lower- and middle-class white men might use violence against people of color, while upper-class whites might resort to private clubs or righteous indignation against "diversity" and "reverse discrimination." 76 Institutions - government bodies, schools, corporations - also perpetuate racism through a variety of overt and covert means. ${ }^{77}$

kansas National Guard employees subjected to racist language and jokes, physical threats, being called "boy," a noose hanging in a supply room, the office mail cart used to spread hate messages including "the only good $n-r$ is a dead $n-r$," and other obscene defamation so extreme it is not included in this footnote). See also Chicago v. Lambert, 47 Ill. App. 2d 151, 197 N.E. 2d 448 (1964) (prosecution for hate speech degrading Jews and African Americans - hate literature reprinted with opinion).

73. This official line masks the commonality of elite participation in racist violence. See $\mathrm{H}$. Shapiro, White VIOLENCE AND Black RESPONSE: From ReCONSTRUCTION TO MONTGOMERY (1988). Shapiro notes the history of white elite participation in and support for violence against African Americans, and notes that, given the historical prevalence of violence generated by white racism, "it is one of the ironies of contemporary experience that many Americans have been conditioned to associate violence with the behavior of black people." Id. at xi.

74. Adrienne Rich recalls the social conduct of upper-class southern whites that expressed racism in polite language, such as the expression, "That's white of you." A. RICH, BLOOD, BREAD, AND POETRY 103, 106 n.2 (1986).

75. I have heard many anti-African-American, anti-Latino, and anti-Semitic comments by people who assume that Asian Americans are not offended by such speech. I have heard these comments in law firms, at universities, and at fancy dinner parties, as well as in working-class settings. In my efforts of private reprimand for racist speech, I have found upper-class speakers more likely to defend their racism. When I objected to the statement that members of an ethnic group are welfare cheaters, the wealthy woman who made the statement proceeded to provide "evidence" that she was correct. When I objected to an L.A. cabdriver's similar statement, he responded, "Lady, I grew up among garbage and garbage comes out of my mouth," and he apologized for offending me.

76. See H. Schuman, C. STEEH \& L. BoBo, supra note 68, at 202-05 (showing longitudinal changes in American public opinion favoring equality but resisting remedial steps to implement equality); Kinder, The Continuing American Dilemma: White Resistance to Racial Change 40 Years After Mydral, $42 \mathrm{~J}$. Soc. Issues 151 (1986) (Symbolic racism blends values of individualism and self-reliance with racism. This modern form is evidenced in opposition to busing, affirmative action, and African-American candidates for office, and agreement with statements that African Americans are demanding too much.); Sears, Hensler \& Speer, Whites' Opposition to "Busing": Self-Interest or Symbolic Politics?, 73 AM. PoL. SCI. REv. 369 (1979) (discussing "symbolic racism" and the ways in which deep seated fears are converted into opposition to busing or affirmative action); see also Pettigrew, New Patterns of Racism: The Different Worlds of 1984 and 1964, 37 RUTGERS L. REv. 673, 687-92 (1985) (identifying features of modern prejudice, including: (1) rejection of gross stereotypes, (2) compliance without internalization of racial acceptance, (3) emotional ambivalence, (4) micro-aggressions - use of nonracial objections to racial change, (5) sense of subjective threat, (6) individualistic conceptions of opportunity).

77. See W. SEDLACEK \& G. BROoKs, supra note 68, at 5-7 (discussing "How Racism Operates"). Government officials are frequently caught using racist slurs. See, e.g., T. BELL, THE 
From the victim's perspective, all of these implements inflict wounds, wounds that are neither random nor isolated. Gutter racism, parlor racism, corporate racism, and government racism work in coordination, reinforcing existing conditions of domination. Less egregious forms of racism degenerate easily into more serious forms.

The Japanese-American executive who resigns in protest when his employer starts publishing anti-Japanese slogans to improve sales knows that there is a connection between racist words and racist deeds. The racially motivated beating death of Vincent Chin by unemployed white auto workers in Detroit, during a time of widespread anti-Asian propaganda in the auto industry, was no accident. ${ }^{78}$ Nor was the murder of the Davis, California, high school student Thong Hy Huynh, after months of anti-Asian racial slurs. ${ }^{79}$

Violence is a necessary and inevitable part of the structure of racism. ${ }^{80}$ It is the final solution, as fascists know, barely held at bay while the tactical weapons of segregation, disparagement, and hate propaganda do their work. The historical connection of all the tools of racism is a record against which to consider a legal response to racist speech.

\section{The Specific Negative Effects of Racist Hate Messages}

everywhere the crosses are burning,

sharp-shooting goose-steppers around every corner,

there are snipers in the schools...

(I know you don't believe this.

You think this is nothing

but faddish exaggeration. But they

are not shooting at you.)

Lorna Dee Cervantes ${ }^{81}$

Thirteenth Man: A Reagan Cabinet Memoir 104 (1987) (Dr. Martin Luther King, Jr. referred to as a "c-n"; Arabs referred to as "sand $n-r s$ " by members of the Reagan White House staff).

78. See They Don't All Wear Sheets, supra note 38, at 17 ("There are no areas of the country where white supremacist organizations have been extremely active without correspondingly high levels of bigoted violence."). Anti-Asian racist slurs used by auto-industry and trade executives are documented in Asia Bashing: Bias Against Orientals Increases with Rivalry of Nations' Economics, Wall St. J., Nov. 28, 1986, at 1, col. 1. For a history of attacks on Asian Americans during times of perceived threat from "foreigners," see ATTORNEY GENERAL's REPORT, supra note 47, at 33-39.

79. AtTORNEY GENERAL's REPORT, supra note 47 , at 44.

80. A dramatic increase in racist violence and murder occurred in the late $1980 \mathrm{~s}$, particularly associated with the skinheads. See Reports of Racial Violence on the Rise, Klanwatch Intelligence Report, Feb. 1989, at 9, col. 1; see also Los ANGELes CounTy CoMmN. ON Human Relations, Hate Crime in Los ANGeles CounTY 1988, at 1 (1989) [hereinafter Hate CRIME IN L.A.] (reporting escalation of hate crimes beginning in 1986 and 1987, continuing through 1988, after a period of decline in the mid-1980s).

81. Cervantes, Poem for the Young White Man Who Asked Me How I, An Intelligent Well- 
Racist hate messages are rapidly increasing and are widely distributed in this country using a variety of low and high technologies. ${ }^{82}$ The negative effects of hate messages are real and immediate for the victims. $^{83}$ Victims of vicious hate propaganda have experienced physiological symptoms and emotional distress ranging from fear in the gut, rapid pulse rate and difficulty in breathing, nightmares, post-traumatic stress disorder, hypertension, psychosis, and suicide. ${ }^{84}$ Professor Pa-

Read Person Could Believe in the War Between Races, in M. SANChEz, ConTEMPoRARY CHICANA POETRy 90 (1986).

82. For a history of hate group activity, see SOUTHERn POVERTY LAW CENTER, THE KU KLUX KLAN: A HISTORY OF RACISM AND VIOLENCE (3d ed. 1988) (noting history and recent rise of $\mathrm{KKK}$, and growing coalition of violent right-wing hate groups in the United States, including neo-Nazis, survivalists, skinheads, and the KKK). Hate messages are spread through anonymous phone calls and letters, posters, books, magazines and pamphlets, cable television, recorded phone messages, computer networks, bulk mail, graffiti, and leafletting. See CiviL Rights Division, ANTI-Defamation League of B'NaI B'RITH, SPECIal Edition: ElecTRONIC HATE (1987) (report on use of cable television public access by hate groups); CIVIL Rights Division, ANTi-Defamation League of B'Nai B'RITh, "Shaved For Battle": SKINHEADS TARGET AMERICA's YOUTH (1987) (use of music and youth culture to spread white supremacist ideology and violence); Chin, supra note 57, at 72 (White Aryan Resistance telephone message blaming high insurance rates on Asians and Latinos); Dent, Et Al., STUDENT LAw., Dec. 1984, at 46 (recorded message using the word " $n$-r" 9 times in 75 seconds); Jones, Violence by Skinheads Spreads Across Nation, L.A. Times, Dec. 19, 1988, at 1, col. 3 (reporting 2000-3500 members of violent racist groups using bulk mail, computers, television, and leafleting of schools - particularly in the northwest - to attract growing numbers of new members).

More recent cases show little change in racists' style. See, e.g., License Issue Goes Away, N.Y. Times, Sept. 6, 1986, at 10, col. 1 (reporting sale of KTTL-FM of Dodge City, Kansas, which had urged listeners to "mak[e] dossiers, names, addresses, phone numbers, car license numbers" on all rabbis, in order to "set up ambushes").

83. See, e.g., Wade v. Orange County Sheriff's Office, 844 F.2d 951, 953 (2d Cir. 1988) (African-American sheriff's deputy suffered emotional distress and humiliation from racial discrimination at work); Wilmington v. J.I. Case Co., 793 F.2d 909 (8th Cir. 1986) (African-American lswelder suffered several years of racial harassment and employment discrimination resulting in severe health complications). The harm of racist insult is discussed extensively in Delgado, supra note 6. Delgado cites classic psychological evidence of the destruction of self-worth by racist attitudes.

84. Effects of racial prejudice include displaced aggression, avoidance, retreat, withdrawal, alcoholism, and suicide. H. KITANO, supra note 68, at 113; see also G. ALLPORT, supra note 32, at 141-61 (psychological responses to racist victimization include withdrawal, clowning, strengthening in-group ties, self-hate, militancy, status-striving, and the self-fulfilling prophecy); ATTORNEY GENERAL's REPORT, supra note 47, at 45 (racial epithets and harassment "often cause deep emotional scarring, and bring feelings of intimidation and fear that pervade every aspect of a victim's life"); Delgado, supra note 6 (noting, inter alia, high blood pressure, loss of self-worth, and special harm to children); $c f$. Denis, supra note 41 , at 415 (discussing damages for psychic injury in race harassment cases); Häfner, Psychological Disturbances Following Prolonged Persecution, Soc. PSYCHIATRY, July 1968, at 79 (discussing psychological symptoms including headaches, dizziness, social withdrawal, chronic depression, and anxiety neurosis in survivors of extreme persecution). The unprovoked and unpredictable nature of bigoted attacks adds to the anxiety they create. African Americans have been subjected to racist attacks while engaging in commonplace activities such as changing a tire or attending a church picnic. See HATE Groups, supra note 38 , at 5 . Victims have had some limited success in proving emotional distress and psychological damage from racist messages. See, e.g., Vance v. Southern Bell Tel. \& Tel. Co., 672 F. Supp. 1408 (M.D. Fla. 1987), affd. in part, revd. in part, 863 F.2d 1503 (11th Cir., 1989) (woman subjected to repeated racial harassment, including nooses hanging over her desk, suffered nervous breakdown). 
tricia Williams has called the blow of racist messages "spirit murder" in recognition of the psychic destruction victims experience. ${ }^{85}$

Victims are restricted in their personal freedom. In order to avoid receiving hate messages, victims have had to quit jobs, forgo education, leave their homes, avoid certain public places, curtail their own exercise of speech rights, and otherwise modify their behavior and demeanor. ${ }^{86}$ The recipient of hate messages struggles with inner turmoil. One subconscious response is to reject one's own identity as a victimgroup member. ${ }^{87}$ As writers portraying the African-American experience have noted, the price of disassociating from one's own race is often sanity itself. 88

As much as one may try to resist a piece of hate propaganda, the effect on one's self-esteem and sense of personal security is devastat-

85. Williams, supra note 34 , at 129.

86. See, e.g., EEOC v. St. Anne's Hosp., 664 F.2d 128 (7th Cir. 1981) (African-American employee fired after hospital receives racist bomb threats for hiring African Americans); Sambos Restaurants, Inc. v. City of Ann Arbor, 663 F.2d 686, 703 (6th Cir. 1981) (Keith, J., dissenting) (African Americans tend to avoid public facilities with racially offensive names); HATE GROUP ACTIVITY, supra note 61, at 20 (discussing case of a fourteen-year-old boy who was the subject of Klan leafleting campaign and became so frightened he dropped out of school); $i d$. at 23 (citing testimony of State Representative and civil rights leader, Hosea Williams, to the effect that he has become leery of civil rights marches because after outsiders leave, local whites harass local African Americans).

See also Letter from Bobby Person (July 3, 1986) (distributed by the Southern Poverty Law Center) (prison guard, the first African American to attain the rank of sergeant, was harassed with a cross burning and KKK visits); Denis, supra note 41 (citing several cases of race harassment in the workplace); Dent, supra note 82, at 48 (African-American Naval Reserve ensign resigns from officers' school after threats from "Navy KKK"). At the other end of the spectrum, racial stereotyping carries daily modification of behavior and dress to counteract stereotypes. See Lieberson, Stereotypes: Their Consequences for Race and Ethnic Interaction, in RESEARCH ON RACE AND ETHNic ReLations 113 (C. Marrett \& C. Leggon eds. 1985).

Professor Judith Weightman has told me that, in conducting interviews with Japanese-American World War II veterans, she noted denial of discrimination that, upon questioning, turned to an admission that informants simply avoided places, organizations, and events that perpetuated anti-Japanese exclusion and thus could report "not experiencing" discrimination. See also H. KITANO, supra note 68, at 113-14 (discussing ways in which ethnics avoid situations where they will encounter prejudice).

87. When this writer confronted a cityful of anti-Asian posters, a strange process of disassociation occurred. "Not me, they must mean those immigrants." One researcher of racially motivated crime noted that "victims will deny it's a hate crime. If you feel you're a victim because of your religion or your color, then each time you step out the door [you fear] you're going to be attacked." Professor Jack McDevitt, Center for Applied Social Research at Northeastern University, quoted in Bigots' Crimes, supra note 63. See also H. KITANO, supra note 68, at 113-14 (discussing the "passing" syndrome).

88. See Baldwin, African Self-Consciousness and the Mental Health of African-Americans, 15 J. Black Studies 177 (1984) ("Alien self" in African Americans comes from identifying with Europeans); cf. Minow, The Supreme Court, 1986 Term - Foreword: Justice Engendered, 101 HARV. L. REV. 10, 67-68 (discussing tendency of outsider groups to "internalize the views" of the dominant group); Cervantes, supra note 81 ("Let me show you my wounds: my stumbling mind, my 'excuse me' tongue, and this nagging preoccupation with the feeling of not being good enough.”). See generally W. Grier \& P. CobbS, Black Rage (1968). 
ing. ${ }^{89}$ To be hated, despised, and alone is the ultimate fear of all human beings. However irrational racist speech may be, it hits right at the emotional place where we feel the most pain. The aloneness comes not only from the hate message itself, but also from the government response of tolerance. When hundreds of police officers are called out to protect racist marchers, ${ }^{90}$ when the courts refuse redress for racial insult, and when racist attacks are officially dismissed as pranks, the victim becomes a stateless person. Target-group members can either identify with a community that promotes racist speech, or they can admit that the community does not include them.

The effect on non-target-group members is also of constitutional dimension. Associational and other liberty interests of whites are curtailed by an atmosphere rife with racial hatred.91 In addition, the process of dissociation can affect their mental health. Dominant-group members who rightfully, and often angrily, object to hate propaganda share a guilty secret: their relief that they are not themselves the target of the racist attack. While they reject the $\mathrm{Ku}$ Klux Klan, they may feel ambivalent relief that they are not African-American, Asian, or

89. As one student reported after watching harassment of an African-American professor at Dartmouth, "That moment let me know that there are people in this world who hate you just because of your color. Not dislike you, or choose not to be friends with you, but hate you." Wiener, supra note 71 , at 260 . Any practicing psychotherapist knows of adults forever scarred by an early message of "you're not good enough," which creates lifelong feelings of inadequacy and inability to experience inner joy at one's achievements and abilities. I thank my student Terry Wade, a psychotherapist, for this insight.

90. See 6 Protesters Arrested at Houston Klan March, N.Y. Times, Apr. 3, 1983, at 23, col. 1 (six hundred police in riot gear protected $\mathrm{Ku}$ Klux Klan marchers in Houston).

91. Hate messages, threats, and violence against whites is often the price of hiring, marrying, adopting, socializing with, and even jogging with, people of color. See EEOC v. St. Anne's Hospital, 664 F.2d 128 (7th Cir. 1981) (bomb threat for hiring an African American); Guillory v. Godfrey, 134 Cal. App. 2d 628, 286 P.2d 474 (1955) (white woman suffers nervous breakdown after hiring a black cook to work in her restaurant, as a result of constant racist harassment from neighbors); HATE Group ACTIVITY, supra note 61, at 19 (Gene Guerrero, Executive Director, ACLU of Georgia, testified of repeated harassment of a white woman recreation director who supervised integrated children. After cross burnings and KKK letters directed at her, she decided to flee to another state.); THEY Don'T ALL WEAR SHEETS, supra note 38, at 13; YouNG AND VIOLENT, supra note 5, at 11 (reporting skinhead murder of white musician who brought an African American to a party in Santa Clara, California); Dent, supra note 82, at 48 (Estacada, Oregon home of interracial couple vandalized with KKK graffiti); 5 Youths Charged After Store Melee Under New Ethnic Intimidation Law, Detroit Free Press, Apr. 26, 1989, at 4A, col. 3 (skinheads harass and attack white man walking with three African Americans); see also United States v. Original Knights of the Ku Klux Klan, 250 F. Supp. 330, 339 (E.D. La. 1965) (Klan rules require boycott of whites who, inter alia, "serve[] Negroes and whites on an integrated basis" or "allow[] Negroes to use White rest rooms" and adding that a Klan member who patronizes boycotted whites "shall be wrecked by the wrecking crew who shall be appointed by the Committee."). Judge Wisdom's opinion chronicled instances of the Klan interfering with the exercise of civil rights and first amendment rights in Bogalusa, Louisiana, including notices that "we have KLAN members in every conceivable business.... [W] take this means to urge all of you to refrain from attending this meeting. Those who do attend [are] integrationists and will be dealt with accordingly ...." 250 F. Supp. at 343. 
Jewish. Thus they are drawn into unwilling complacency with the Klan, spared from being the feared and degraded thing.

Just as when we confront human tragedy - a natural disaster, a plane crash - we feel the blessing of the fortunate that distances us from the victims, the presence of racist hate propaganda distances right-thinking dominant-group members from the victims, making it harder to achieve a sense of common humanity. Similarly, racist propaganda forces victim-group members to view all dominant-group members with suspicion. ${ }^{92}$ It forces well-meaning dominant-group members to use kid-glove care in dealing with outsiders. ${ }^{93}$ This is one reason why social relations across racial lines are so rare in America.

Research in psychosocial $^{94}$ and psycholinguistic ${ }^{95}$ analysis of racism suggests a related effect of racist hate propaganda: at some level, no matter how much both victims and well-meaning dominant-group members resist it, racial inferiority is planted in our minds as an idea that may hold some truth.96 The idea is improbable and abhorrent, but it is there before us, because it is presented repeatedly. "Those people" are lazy, dirty, sexualized, money-grubbing, dishonest, inscru-

92. As one student wrote in the midst of controversy over a racist poster at the University of Virginia, "How can I, the Average White Student, communicate to the "black community' that I am not racist?" The student went on to argue that "bigotry" and "racism" are as insulting as racial epithets and to decry "hostility and suspicion." Whether the student's analysis is correct, it carried a tone of genuine frustration at the lack of collegial relations between African American and white students during the poster controversy. Letter to the Editor, University Journal (University of Virginia), Nov. 4, 1988, at 4, col. 2. As one sensitive student wrote to me, his WASP-ness subjects him to "double ostracism - from whites who cannot stand my [anti-racist] attitude and outsiders who look at my skin and distrust."

93. Cf. Brislin, Prejudice and Intergroup Communication, in INTERGRoup COMMUNication 74, 74 (W. Gudykunst ed. 1986) (white anxiety stemming from conscious desire to overcome history of prejudice in society "can be interpreted as coldness or lack of spontaneity"); Weitz, Attitude, Voice, and Behavior: A Repressed Affect Model of Interracial Interaction, 24 J. PERSONALITY \& Soc. PSYCHOLOGY 14, 20 (1972) (whites treated African Americans with "verbal overfriendliness, coupled with vocal and behavioral cues of affective retreat").

94. For discussion of the psychology of negative associations with blackness, see W. JORDAN, White over Black: American AtTitudes Toward THE Negro, 1550-1812 (1968); J. KOVEL, WhITE RACISM: A PsYchohisToRy (1970); Frank \& Gilovich, The Dark Side of Selfand Social Perceptions: Black Uniforms and Aggression in Professional Sports, 54 J. PERSONALITY \& Soc. Psychology 74 (1988) (more penalties assessed to teams in black uniforms).

95. The field of psycholinguistics studies the relationship between language and human behavior, exploring the ways in which the words we hear and speak can affect our behavior. See L. Fergenson, Group Defamation, From Language to Thought and Action (unpublished paper presented at the Hofstra University Conference on Group Defamation \& Freedom of Speech, Apr. 21, 1988) citing, inter alia, H. ClaRK \& E. ClaRK, Psychology and Language: AN Introduction to Psycholinguistics (1977). See also Media Violence and Antisocial Behavior, J. Soc. Issues, No. 3, 1986, at 1 (L.R. Huesmann \& N. Malamuth eds.).

96. Psychological study of cueing behavior indicates that overhearing a racist slur causes the listener to evaluate members of the slurred group more harshly in the future. Greenberg \& Pyszczynski, The Effect of an Overheard Ethnic Slur on Evaluations of the Target: How to Spread a Social Disease, 21 J. EXPERIMENTAL Soc. Psychology 61, 70 (1985). 
table, we are told. ${ }^{97}$ We reject the idea, but the next time we sit next to one of "those people" the dirt message, the sex message, is triggered.98 We stifle it, reject it as wrong, but it is there, interfering with our perception and interaction with the person next to us. ${ }^{99}$ For the victim, similarly, the angry rejection of the message of inferiority is coupled with absorption of the message. When a dominant-group member responds favorably, there is a moment of relief - the victims of hate messages do not always believe in their insides that they deserve decent treatment. This obsequious moment is degrading and dispiriting when the self-aware victim acknowledges it. 100

Psychologists and sociologists have done much to document the effects of racist messages on both victims and dominant-group members. ${ }^{101}$ Writers of color have given us graphic portrayals of what life is like for victims of racist propaganda. ${ }^{102}$ From the victim's perspective ${ }^{103}$ racist hate messages cause real damage. ${ }^{104}$

97. See, e.g., Steplan \& Rosenfield, Racial and Ethnic Stereotypes, in IN THE EYE OF THE Beholder: CONTEMPORARY IsSUES IN STEREOTYPING 92 (A. Miller ed. 1982) (persistence of negative stereotyping of African Americans).

98. Cf. Gardner \& Taylor, Ethnic Stereotypes: Their Effects on Person Perception, 22 CANADIAN J. PsYCHOLOGY 267 (1968); Lobel, Effects of Personal Versus Impersonal Rates Instructions on Relative Favorability of Thirteen Ethnic Group Stereotypes, 128 J. Soc. PsYCHOLOGY 29 (1987) (citing various studies of prejudice and stereotyping).

99. Another story: In conducting research for this Article, I read an unhealthy number of racist statements. A few weeks after reading about a "dotbusters" campaign against immigrants from India, I passed by an Indian woman on my campus. Instead of thinking, "What a beautiful sari," the first thought that came into my mind was "dotbusters." Only after setting aside the hate message could I move on to my own thoughts. The propaganda I read had taken me one step back from casually treating a fellow brown-skinned human being as that, rather than as someone distanced from myself. (Numerous incidents of racially motivated violence and hate speech against Asian Indians have occurred in recent years. See APAC Alert, supra note 57.)

100. Professor Patricia Williams does us a service in addressing this phenomenon in her courageous writing for this symposium. See Williams, supra note 10.

101. See G. AlLPORT, supra note 32; H. Kitano, supra note 68, at 113-14 (discussing effects of prejudice); H. Schuman, C. STEEH \& L. BoBo, supra note 68, at 123, 137 (negative responses to Ku Klux Klan declining in public opinion). In addition to harm to victims, racist speech in a way harms the speaker, by causing the speaker's isolation and escalating racism. See Abelson, Beliefs Are Like Possessions, 16 J. TheORY Soc. BeHAv. 227, 228 (1986) (insults cause arguers to become more extreme in their positions). As we learn more about the compulsive/ psychosocial aspects of racism, we may come to see how allowing the racist speaker to fall into an accelerating upward spiral of racist behavior is akin to letting a disease go untreated. The paternalistic ring of the disease model causes dis-ease given our knowledge of the harm done under that model to innocent nonconformists, the weak, the poor, women, and children. On the other hand, extreme libertarian individualism denies the racists the opportunity to know what life might be like if their escalating racism were to be restrained. This possibility is particularly poignant considering the young children socialized into racism in "junior klan" organizations. See supra note 71.

102. See, e.g., Afro-American Writing (R. Long \& E. Collier eds. 1985).

103. Alan Freeman recognized the value of victim perspective in his article, Antidiscrimination Law: A Critical Review, in The Politics of LAw 96 (D. Kairys ed. 1982).

104. David Matas, National Chair of the League of Human Rights of B'nai B'rith, Canada, noted in the Canadian context that the World War II internment of Japanese Canadians, and the 
If the harm of racist hate messages is significant, and the truth value marginal, the doctrinal space for regulation of such speech is a possibility. An emerging international standard seizes this possibility.

\section{INTERNATIONAL LAW OF HUMAN RIGHTS - EMERGING ACCEPTANCE OF THE VICTIM's STORY}

The international community has chosen to outlaw racist hate propaganda. Article 4 of the International Convention on the Elimination of All Forms of Racial Discrimination states:

\section{Article 4}

States Parties condemn all propaganda and all organizations which are based on ideas or theories of superiority of one race or group of persons of one colour or ethnic origin, or which attempt to justify or promote racial hatred and discrimination in any form, and undertake to adopt immediate and positive measures designed to eradicate all incitement to, or acts of, such discrimination and, to this end, with due regard to the principles embodied in the Universal Declaration of Human Rights and the rights expressly set forth in article 5 of this Convention, inter alia:

(a) Shall declare as an offence punishable by law all dissemination of ideas based on racial superiority or hatred, incitement to racial discrimination, as well as all acts of violence or incitement to such acts against any race or group of persons of another colour or ethnic origin, and also the provision of any assistance to racist activities, including the financing thereof;

(b) Shall declare illegal and prohibit organizations, and also organized and all other propaganda activities, which promote and incite racial discrimination, and shall recognize participation in such organization or activities as an offence punishable by law; [and]

(c) Shall not permit public authorities or public institutions, national or local, to promote or incite racial discrimination. ${ }^{105}$

Under this treaty, states are required to criminalize racial hate messages. Prohibiting dissemination of ideas of racial superiority or hatred is not easily reconciled with American concepts of free speech. The Convention recognizes this conflict. Article 4 acknowledges the need for "due regard" for rights protected by the Universal Declaration of Human Rights and by article 5 of the Convention - including the rights of freedom of speech, association, and conscience.

Recognizing these conflicting values, and nonetheless concluding

turning away of Jewish Holocaust refugees in Canada, was a concrete harm resulting from hate propaganda. D. Matas, Should Zundel Have Been Prosecuted?, Remarks Prepared for a Seminar in Halifax 3-4 (Mar. 22, 1985) (on file with author).

105. International Convention on the Elimination of All Forms of Racial Discrimination, opened for signature Mar. 7, 1966, 660 U.N.T.S. 195 [hereinafter Racial Discrimination Convention]. 
that the right to freedom from racist hate propaganda deserves affirmative recognition, represents the evolving international view. An American lawyer, trained in a tradition of liberal thought, would read article 4 and conclude immediately that it is unworkable. Acts of violence, and perhaps imminent incitement to violence are properly prohibited, but the control of ideas is doomed to failure. This position was voiced continually in the debates ${ }^{106}$ preceding adoption of the Convention, leading to the view that article 4 is both controversial and troublesome. ${ }^{107}$

To those who struggled through early international attempts ${ }^{108}$ to deal with racist propaganda, the competing values had a sense of urgency. ${ }^{109}$ The imagery of both book burnings and swastikas was clear in their minds. ${ }^{10}$ Hitler had banned ideas. He had also murdered six million Jews in the culmination of a campaign that had as a major theme the idea of racial superiority. While the causes of fascism are complex, ${ }^{111}$ the knowledge that anti-Semitic hate propaganda and the rise of Nazism were clearly connected guided development of the emerging international law on incitement to racial hatred.

In 1959 and 1960, the United Nations faced an "outburst of antiSemitic incidents in several parts of the world." 112 The movement to implement the human rights goals of the United Nations Charter and of the Universal Declaration gained momentum as member states sought effective means of eliminating discrimination. ${ }^{113}$

106. See N. LeRner, The U.N. Convention on the Elimination of All Forms of Racial Discrimination 43-53 (2d ed. 1980).

107. See $i d$. at 53.

108. The article is the result of many attempted rewordings and compromises, going back to the first attempts at formation of an international bill of rights. In 1949, the Commission on Human Rights, chaired by Eleanor Roosevelt, proposed a draft International Covenant on Human Rights. The draft was an early attempt to concretize the "lofty principles" of the Universal Declaration of Human Rights. The draft enumerated several specific rights, and imposed obligations of implementation upon member states. Between article 20, governing equal protection before the law, and article 22, avoiding construction of the covenant that would destroy rights protected therein, is a noticeable gap. There is no article 21. Instead, the Commission left a notation that it had postponed discussion of article 21, which, in a version proposed by France, refers to incitement to violence through "advocacy of national, racial, or religious hostility." Text of Draft International Covenant on Human Rights As Submitted to Member Governments for Consideration and Comment, 1949 Y.B. ON HuM. RTS. 332, 336, U.N. Sales No. 1951.XIV.I. The problem of racist speech, it seems, was not one the Commission was ready to deal with in 1949.

109. The Italian representative, for example, spoke of the millions of victims of racial hatred "in our generation." N. LERNER, supra note 106, at 10.

110. In 1963, the General Assembly adopted the Declaration on the Elimination of All Forms of Racial Discrimination in response to "outbursts of swastica painting around the world in 1959-60." R. Lillich \& F. NEWMAN, INTERNATional Human Rights 130 (1979).

111. See generally F. CARsten, The Rise of FAscism (1967).

112. N. LERNER, supra note 106 , at 1.

113. The movement for implementation first focused upon a General Assembly Declaration 
While there was consensus on the basic goal of elimination of discrimination, there was division on the question of incitement to hatred. The Sub-Commission on the Prevention of Discrimination and Protection of Minorities began work in 1964, using drafts prepared by the representatives of the United States, by the United Kingdom, and a joint draft by the representatives of the USSR and Poland. ${ }^{114}$ Thus the Sub-Commission had the benefit of vastly different ideological views as well as a basic consensus on the necessity of combating discrimination.

In addressing incitement, the American draft would have outlawed direct incitement to acts of racist violence. ${ }^{115}$ It would have disallowed government involvement in chartering or supporting racist hate groups. This was consistent with American constitutional principles. The USSR/Poland draft would have banned all "propaganda" of "superiority" and would have criminalized participation in any organization that discriminated or advocated discrimination. ${ }^{116}$ In obvious contrast to the American view, the socialist nations proposed direct action against hate messages, expressing little concern for an individualistic, civil libertarian conception of free speech.

Discussion by the Commission on Human Rights centered around the problems of proving when propaganda was likely to cause violence, and whether violence was the only end to avoid. ${ }^{117}$ The problem of freedom of association and the banning of hate organizations was also discussed. The final decision, by a vote of 16 in favor and 5 abstentions, was to adopt paragraph $4(\mathrm{~b})$ as it is now written, banning propaganda activity that promoted discrimination, and criminalizing participation in organizations promoting discrimination. ${ }^{118}$ The weaker American position was thus rejected by the Commission.

The proposed convention next went to the Third Committee of the General Assembly in 1965. Again the issues of the necessity of ties to

on the Elimination of All Forms of Racial Discrimination. G.A. Res. 1904, 18 U.N. GAOR Supp. (No. 15) at 35, U.N. Doc. A/5515 (1963).

114. N. LERNER, supra note 106, at $4-5$.

115. Revised draft of article 4 submitted to the Sub-Commission by Mr. Abram, Sub-Commission on Prevention of Discrimination and Protection of Minorities, U.N. Doc. E/CN.4/ Sub.2/L.308/Add.1/Rev.1 (1964). This view is consistent with American case law. See, e.g., Brandenburg v. Ohio, 395 U.S. 444 (1969).

116. Draft of article 4 submitted by Messrs. Ivanov and Ketrzynski, Sub-Commission on Prevention of Discrimination and Protection of Minorities, U.N. Doc. E/CN.4/Sub.2/L.314 (1964).

117. See N. LERNER, supra note 106, at 44-45 (discussions among, inter alia, representatives of Denmark, India, and Costa Rica on the role of incitement to violence).

118. Id. at 45 . 
violence and of recognition of free speech rights were raised. ${ }^{119}$ The United States proposed explicit recognition of the right of free speech within the text. ${ }^{120}$ The Committee chose instead to refer generally to "due regard" of article 5 rights. Acts of violence were prohibited, but the final form of the proposed article went further. It also outlawed the mere dissemination of racist ideas, without requiring proof of incitement. An atmosphere of hatred, it was argued by the Polish representative, would inevitably lead to discrimination. ${ }^{121}$

When the draft finally reached the General Assembly, Argentina, Colombia, Ecuador, Panama, and Peru - countries relatively friendly to the United States - proposed deletion of the dissemination-of-ideas language. This amendment was rejected -54 against, 25 in favor, and 23 abstaining ${ }^{122}$ - but the limited consensus on this point indicates the controversial nature of the article. Notably, in other areas of international human rights consensus building, serious ideological controversy dooms a proposal to failure. Language banning anti-Semitism, for example, died a political death because of Arab and Soviet concerns that the charge of anti-Semitism would be used as a political weapon against them. ${ }^{123}$ Article 4 is unique in that a clearly controversial proposition survived in the final Convention. The survival of article 4 , in spite of the controversy, indicates the overriding strength of the basic idea that promotion of racism is a serious threat to the protection of human rights.

The General Assembly debates on article 4 focused on free speech. While the issue was never clearly resolved, it is significant that no country, not even the United States, was willing to abandon the basic premise of article 4 . The article declares that states parties "condemn all propaganda . . . based on ideas or theories of superiority . . . or which attempt[s] to justify or promote racial hatred and discrimination in any form." 124 Similarly, the preamble to the Convention states explicitly that "any doctrine of superiority based on racial differentiation is scientifically false, morally condemnable, socially unjust and dangerous, and that there is no justification for racial discrimination." ${ }^{125}$ The community of nations has thus made a commitment,

119. Id. at $45-46$.

120. Id. at 46.

121. Mr. Ketrzynski, Sub-Commission on Prevention of Discrimination and Protection of Minorities, U.N. Doc. E/CN.4/Sub.2/SR.418 at 14-15 (1964).

122. N. LERNER, supra note 106, at 46.

123. See id. at 71-73; McDougal, Lasswell \& Chen, The Protection of Respect and Human

Rights: Freedom of Choice and World Public Order, 24 AM. U. L. REv. 919, 1059-60 (1975).

124. Racial Discrimination Convention, supra note 105, at 218.

125. Id. at 214. 
with United States support, to the elimination of racism. It has recognized that racist hate propaganda is illegitimate and properly subject to control under the international law of human rights. The debate, then, centers around the limits of such control, not around the basic decision to control racism.

The Convention, including article 4, was unanimously adopted by the General Assembly on December 21, 1965.126 Under U.N. treaty procedure, it entered into force on January 4, 1969, and gathered an increasing number of state signatures over the years. ${ }^{127}$ The United States was an early signatory to the convention, consistent with its significant role in drafting and promoting the convention from the earliest stages. In 1978 President Carter submitted the convention to the Senate for ratification. ${ }^{128}$ The Senate has taken no significant steps toward ratification. Signature does not bind the United States to the treaty until the signing is ratified. Under the Vienna Convention on the Law of Treaties a state's signature does, however, bind it to refrain from defeating the object of the treaty. ${ }^{129}$

The procedure for signature and ratification allows reluctant states to reserve the right to reject antipropaganda laws that would interfere with the right of free speech. ${ }^{130}$ Such states apparently felt that the "due regard" clause of article 4 was not explicit enough to reserve this right.

Some commentators suggest that the United States should not ratify the Convention without explicit reservation to article 4 , because the due regard clause is not "a sufficient safeguard for the rights set forth in the First Amendment."131 In signing the Convention, the United States made a relatively short reservation, stating:

The Constitution of the United States contains provisions for the protection of individual rights, such as the right of free speech, and nothing in the Convention shall be deemed to require or to authorize legislation or other action by the United States of America incompatible with the provisions of the Constitution of the United States of America. ${ }^{132}$

This limited reservation indicates the United States' basic position of support for the Convention. Such support is consistent with the

126. 20 U.N. GAOR (1406th plen. mtg.) at 7, U.N. Doc. A/PV.1406 (1965).

127. N. LERNER, supra note 106 , at 155.

128. R. Lillich \& F. Newman, supra note 110 , at 130.

129. Vienna Convention on the Law of Treaties, done May 23, 1969, art. 18, 1155 U.N.T.S. $331,336$.

130. Racial Discrimination Convention, supra note 105, art. 20, at 236.

131. N. Nathanson \& E. Schwelb, The United States and the United Nations

Treaty on RaCial. Discrimination 8 (Studies in Transnational Legal Policy No. 9, 1975).

132. Id. at 85 . 
American ideological commitment to equality and with the need to maintain international prestige. ${ }^{133}$ The reservation and the failure to ratify the convention separates the United States from an evolving world standard. As discussed below, this position represents an extreme commitment to the first amendment at the expense of antidiscrimination goals.

The Convention is not the only expression of the emerging international view. The need to limit racist hate messages is implicit in basic human rights documents such as the United Nations Charter and the Universal Declaration of Human Rights. Both documents recognize the primacy of the right to equality and freedom from racism. ${ }^{134}$ Other human rights treaties, such as the European Convention for the Protection of Human Rights and Fundamental Freedoms ${ }^{135}$ and the American Declaration of the Rights and Duties of $\mathrm{Man}^{136}$ also recognize this primacy. The United States is also a party to an international convention on genocide that forbids, inter alia, incitement to genocide. ${ }^{137}$ Finally, the existing domestic law of several nations - including states that accept the western notion of freedom of expression has outlawed certain forms of racist speech. ${ }^{138}$

The United Kingdom, for example, under the Race Relations Act, has criminalized incitement to discrimination and incitement to racial hatred.139 The Act criminalizes the publication or distribution of "threatening, abusive, or insulting" written matter or use of such language in a public place. The United Kingdom standard originally differed from the international standard in that it required proof of intent

133. Cf. Dudziak, Desegregation as a Cold War Imperative, 41 STAN. L. REv. 61 (1988) (history of linkage between U.S. support for antidiscrimination law and claims of moral superiority to the socialist world).

134. See U.N. Charter art. 55(c); Universal Declarion of Human Rights, G.A. Res. 217A (III), U.N. Doc. A/810, at 71 (1948).

135. Council of Europe, European Convention on Human Rights: Collected TEXTS, $§ 1$ (7th ed. 1971).

136. Pan american Union, Final act of the Ninth International Conference of American States 38 (1948).

137. The Convention of the Prevention and Punishment of the Crime of Genocide, art. 3(c), adopted Dec. 9, 1948, 78 U.N.T.S. 277, 280, requires member states to prohibit "[d]irect and public incitement to commit genocide." The Convention was ratified by the United States Senate in 1986 with reservations noting that the United States Constitution would override any provisions of the Convention. 132 CONG. REC. 2349-50 (Feb. 19, 1986).

138. For an excellent review of European anti-hate speech laws, see Kretzmer, supra note 36, at 499-506. Domestic states of the United States have also enacted anti-hate group legislation and constitutional provisions, such as group libel laws. See, e.g., ILL. CoNST. art. 1, § 20; FLA. STAT. $\S \S 876.17-.20$ (1987); N.C. GEN. STAT. §§ 14.12-.14 (1986); OKLA. STAT. tit. 21 , $\S 1301$ 1306 (1981).

139. Race Relations Act of 1965 , ch. $73 \S 6(1)$, amended in 1976 and 1986. 
to incite to hatred. The intent requirement was later dropped. ${ }^{140}$ The Act is consistent with the international standard in that it recognizes that avoiding the spread of hatred is a legitimate object of the law, and that some forms of racist expression are properly criminalized. The legislative history of the Act suggests that the drafters were concerned with the spread of racist violence. ${ }^{141}$ Imminent violence, however, was not the only object of the Act. The Act recognized the inevitable connection between the general spread of race hatred and the spread of violence. While commentators have suggested that the Act is ineffective and capable of misuse, ${ }^{142}$ the existence of the Act supports the growing international movement toward outlawing racist hate propaganda.

Canada has similarly adopted a national statute governing hate propaganda. Sections 318 and 319 of the Canadian Criminal Code ${ }^{143}$ outlaw advocacy of genocide, defined as, inter alia, an act designed to kill a member of an identifiable group. They also outlaw communications inciting hatred against any identifiable group where a breach of peace is likely to follow. The law further outlaws the expression of ideas inciting hatred if such expression is tied to a probable threat to order.

The new Canadian Bill of Rights incorporates strong protections for freedom of speech and association. ${ }^{144}$ Conflict between the new bill of rights and the hate messages legislation has not prevented actions to limit hate speech. ${ }^{145}$

Australia and New Zealand also have laws restricting racist speech, ${ }^{146}$ leaving the United States alone among the major common-

140. See Race Relations Act of 1976 , ch. $74, \S 70$; Kretzmer, supra note 36 , at 501 (discussing amendment dropping intent requirement because it "made it almost impossible to convict").

141. I. MacDonald, Race Relations and Immigration Law $\{8$ (1969).

142. See, e.g., id. at If 203.

143. R.S.C. ch. C-46, $\S \S 318,319$ (1985).

144. Constitution Act of 1982, §2.

145. Canadian cases allowing legal restraint of hate speech include Regina v. Keegstra, 19 C.C.C. (3d) 254 (Alta. Q.B.) (1984), and Regina v. Zundel, 31 C.C.C. (3d) 97, 580 O.R. (2d) 129 (Ont. C.A. 1987).

146. See, e.g., the proposed amendments to the New South Wales Racial Discrimination Act reported in WOOMERA, June/July 1987, at 1 (allowing group defamation actions for racial slurs). Violent racist groups are gaining in membership and visibility in Australia. See Crisp, Harvest of Hate, The Bulletin, Apr. 4, 1989, at 42 (Australian Newsweek); see also J. Griffiths, Confict in Society: Public Order v. Individual Liberty - Laws Against Incitement to Racial Hatred, Paper Delivered at Asia Pacific Lawyers Association Third General Assembly, Hawaii (Jan. 6-9, 1989) (on file with author) (noting anti-incitement act passed in New Zealand in 1971; Australian Broadcasting Tribunal Radio Programme Standard prohibiting material likely to incite race hatred, and proposed legislation in New South Wales banning hate speech). 
law jurisdictions in its complete tolerance of such speech. 147 What these laws and the United Nations Convention have in common is that they specify a particularly egregious form of expression for criminalization. All ideas about differences between races are not banned. The definitive elements are discrimination, connection to violence, and messages of inferiority, hatred, or persecution. Thus the entire spectrum of what could be called racist speech is not prohibited. A belief in intellectual differences between the races, for instance, is not subject to sanctions unless it is coupled with an element of hatred or persecution. What the emerging global standard prohibits is the kind of expression that most interferes with the rights of subordinated-group members to participate equally in society, maintaining their basic sense of security and worth as human beings.

The failure of American law to accept this emerging standard reflects a unique first amendment jurisprudence. This jurisprudence is so entrenched in American law that it at first seems irreconcilable with the values given primacy in article 4 , such as the values of equality and full participation. In order to discuss the significance of this contradiction, it is necessary to consider the American position of tolerance.

\section{The Uniquely American Approach of Protection of Racist Hate Propaganda: The Civil LIBERTARIAN's STORY}

Many foreign lawyers, including those from countries close to the United States in ideology, are perplexed by the uniquely American approach of protection of racist hate organizations. ${ }^{148}$ American citizens themselves express frustration when they find that the Klan and the Nazis are free to march in public places, with publicly financed police protection. This section will state the American position, and attempt to make its strongest case. ${ }^{149}$ This is a starting point for exploring the

147. Nations outside of the common-law world have also adopted domestic anti-hate speech legislation. Professor Frances Olsen shared with me this law from Sweden:

If a person publicly or otherwise in a statement or other communication which is spread among the public threatens or expresses contempt for an ethnic group or other such group of persons with allusion to race, skincolour, national or ethnic origin or religious creed, he shall be sentenced for agitation against ethnic group to imprisonment for at most two years if the crime is petty, to pay a fine.

Swed. Penal CODE ch. 16, $\S 8$ (1986). This statute is also discussed in Lasson, Group Libel Versus Free Speech, When Big Brother Should Butt In, 23 DuQ. L. REv. 77, 88 (1984).

148. Author's discussion of racist speech with foreign lawyers.

149. For a thoughtful judicial exposition of the American position, see Judge Decker's opinion in Collin v. Smith, 447 F. Supp. 676 (N.D. Ill. 1978). While tolerance of hate speech represents dominant first amendment thought, there is a record of thoughtful opposition to this view. See, e.g., Riesman, Democracy and Defamation: Control of Group Libel, 42 Col.UM. L. REV. 727 (1942) (arguing for legal restriction of racist speech). 
dominant story of racism in American social life, and for showing that the American position is neither inevitable nor sound as a matter of democratic theory, constitutional doctrine, or value.

By the American position, I refer to the position that would require reservation to article 4 and forbearance from other efforts to control racist speech, on the ground that restriction of racist hate propaganda and hate organizations is incompatible with the first amendment. ${ }^{150}$ There is no single authoritative assertion of this position. The discussion here thus addresses a composite of mainstream first amendment thinking.

Getting a clear statement of the American position is not easy. First amendment doctrine is notably confused, ${ }^{151}$ but a reading of the cases reveals the following core ideas. ${ }^{152}$ Freedom of expression, the argument goes, is the most fundamental right protected under the Constitution. Democratic, representative government presumes that people are free to think and say whatever they might, even the unthinkable. They can advocate the end of democracy. We risk the chance that they will prevail because to give government the power to control expression is an even greater threat. Power is jealous, and the temptation to stifle legitimate opposition is too great. ${ }^{153}$ Thus under our system, there is "no such thing as a false idea."154 All ideas de-

150. See, e.g., Hauser, United Nations Law on Racial Discrimination, AM. J. INTL. L., Sept. 1970, at 114, 117 ("The [s]enatorial environment, I fear, would be extremely hostile. Civil libertarian groups that I have spoken to have serious doubt about the convention as well. . . . The ideas in Article 4 fly directly against the American idea of free speech."); $N$. LERNER, supra note 106 , at 25-26 ("The long discussion on [a]rticle 4 dealt basically with the problems of freedom of speech and freedom of association, freedoms which are likely to be restricted by the provisions of the Convention."). The American position is exemplified by the results in Brandenburg v. Ohio, 395 U.S. 444 (1969) (free speech rights of Ku Klux Klan leader), and National Socialist Party v. Village of Skokie, 69 Ill. 2d 605, 373 N.E.2d 21 (1978).

At least one Supreme Court case has suggested that state group libel statutes directed at racist hate messages are constitutional. See Beauharnais v. Illinois, 343 U.S. 250 (1952).

For a survey of commentary suggesting that Beauharnais never was or no longer is good law, see 1 N. Dorsen, P. Bender \& B. Neuborne, Political and Civil. Rights in the United STATES 655-59 (4th ed. 1976). For conflicting views of whether the Beauharnais doctrine is still effective, see the majority opinion and dissent in Collin v. Smith, 578 F.2d 1197 (7th Cir. 1978).

151. Archibald Cox states in the conclusion to his book on the first amendment that first amendment cases "often lack the full exposition necessary to fit the decisions into a coherent body of law." A. COX, FREEDOM OF EXPRESSION 89 (1981). Laurence Tribe has called current first amendment doctrine a "patchwork quilt of exceptions." L. TRIBE, ConstiTutional Choices 220 (1985).

152. Professor Frederick Schauer points out that "free speech" is a shorthand for a number of different values and principles. F. Schauer, Free SPEech: A Philosophical ENQuiry (1982).

153. See National Committee Against Repressive Legislation, Petition to the United States 101st Congress (Jan. 1989) (law professors' petition calling for legislation to curb FBI excesses, including infiltration, warrantless searches, court disruption, and surveillance, all without probable cause or public accountability, infringing on legitimate political activity).

154. Gertz v. Robert Welch, Inc., 418 U.S. 323, 339 (1974). 
serve a public forum, and the way to combat anti-democratic ideas is through counter-expression. When all ideas are voiced freely, we have the greatest chance that the right results will obtain.

We have no way of knowing what the right results are in advance. Ideas that were once accepted as truth we now reject. Because our ideas about what we want as a society are changing and emergent, we cannot say that certain ideas are unacceptable. New ideas often meet opposition, and we have seen new ideas, including major advances in civil rights, eventually become the majority position. We have no basis for distinguishing good from bad ideas, and the only logical choice is to protect all ideas. ${ }^{155}$

If the state feels threatened by certain ideas, it is not without recourse. It can use education and counter-speech to combat those ideas. It can control conduct or action arising from those ideas. Thus while the state cannot outlaw a militaristic political party, it can control the stockpiling of weaponry and punish any acts of violence. ${ }^{156}$ Incitement to imminent violence is a related and acceptable point of intervention. ${ }^{157}$ Such control is admittedly less effective than direct and preventive repression, but we have made the commitment to a free society, and we will not become un-free even in self-defense. To do otherwise abandons the basic foundation of democracy, rendering nonsensical any claim to necessity. Furthermore, if we accept that ours is a racist society, that is all the more reason to give primacy to the first amendment. The best means to combat racist oppression is the right of protest. 158

Accepting this extreme commitment to the first amendment is neither easy, nor natural. It is a concept one must learn, ${ }^{159}$ and it barely survives the hard cases. There is much speech that comes close

155. Dean Bollinger suggests that possible truth is not a reason for protecting racist speech. L. Bollinger, supra note 12 , at 242-43. Professor Frederick Schauer has also noted that we have relative levels of uncertainty of the truth-value of any given statement, and that low probability of truth is rationally weighed against the harm of certain speech. F. SCHAUER, supra note 152, at 15-34. To their credit, most civil libertarians avoid claiming possible truth as a basis for protecting racist speech, arguing instead that racist lies must be protected in order to preserve free speech for all. See, e.g., A. NEIER, supra note 36.

156. Attempts to limit hate group activity typically call forth opposition by civil libertarians. See, e.g., Moore, Oregon's Paramilitary Activities Statute: A Sneak Attack on the First Amendment, 20 WillameTTE L. REv. 335 (1984) (criticizing 1983 Or. Laws, ch. 792, § 2 (prohibiting paramilitary assembly, training, and display of paramilitary weaponry)).

157. See Brandenburg v. Ohio, 395 U.S. 444 (1969) (advocacy of violence protected and distinguished from actual, imminent violence).

158. This point was made by Alan Borovoy, a Canadian civil libertarian, in his speech at the State University of New York at Buffalo School of Law. Language as Violence, supra note 3, at 339-44. Mr. Borovoy argued that the tactic of creative tension - of causing offense - is essential to civil rights activists. Id. at 340 .

159. T. EMERSON, THE SYSTEM OF FREEDOM OF EXPRESSION 12 (1970). 
to action. Conspiratorial speech, inciting speech, fraudulent speech, obscene speech, and defamatory speech are examples of words that seem to emerge from human mouths as more than ideas. Examples might include a merchant's lies about the efficacy of a product, a gang leader's order to murder an enemy, sexual description broadcast to an audience of children, and threats of physical harm. ${ }^{160}$ The American doctrine recognizes a few limited categories of speech that take on qualities beyond expression. These areas are doctrinally distinct, ${ }^{161}$ and our commitment to the first amendment value requires the most vigilant scrutiny to avoid suppression of ideas under the guise of controlling conduct. ${ }^{162}$

What the American position means in the area of race is that expressions of the ideas of racial inferiority or racial hatred are protected. Anyone who wants to say that African Americans and Jews are inferior and deserving of persecution is entitled to. However loathsome this idea may be, it is still political speech. The law becomes strong at its edges. If we can hold fast to freedom when it is most difficult to do so, we will avoid making the easy and disastrous mistakes.

The strongest argument against criminalization of racist speech is that it is content-based. ${ }^{163}$ It puts the state in the censorship business, with no means of assuring that the censor's hand will go lightly over "good" as opposed to "bad" speech. ${ }^{164}$ Critics cite the Canadian experience of words of protest and satire mistakenly challenged using race-

160. These examples are suggested in id. at 18. See also Comment, Coercion, Blackmail, and the Limits of Protected Speech, 131 U. PA. L. REV. 1469 (1983).

161. Any categorization of acceptable and unacceptable speech is problematic for civil libertarians. Thus some feminists have argued against antipornography laws, fearing "highly subjective criteria that masquerade as simple, delineating definitions." Brief Amici Curiae of the Feminist Anti-Censorship Taskforce, et al., at 8, American Booksellers Assn. v. Hudnut, 771 F.2d 323 (7th Cir. 1985) (No. 84-3147), affd. mem., 475 U.S. 1001 (1986), reprinted in Hunter \& Law, Brief Amici Curiae of the Feminist Censorship Taskforce, et al., in American Booksellers Association v. Hudnut, 21 U. MICH. J.L. REF. 69, 107 (1988).

162. Thus the act of flag burning is protected because of the idea embodied in the act. See Texas v. Johnson, 109 S. Ct. 2533 (1989).

163. The Skokie court made a strong distinction between conduct and words, suggesting that words that shock because of the idea expressed are absolutely protected from criminal prosecution. Collin v. Smith, 578 F.2d 1197, 1206 (7th Cir. 1978). The possibility of a tort action was left open. 578 F.2d at 1206. See also Collin v. Smith, 447 F. Supp. 676, 686 (N.D. Ill. 1978) ("defendants have no power to prevent plaintiffs from stating their political philosophy, including their opinions of black and Jewish people, however noxious and reprehensible that philosophy may be").

164. In speaking on this topic, I've found the most serious objection raised by lawyers in the audiences is that of the slippery slope - that we must never censor because censorship, once allowed, is beyond control. In answer, I acknowledge that this is the central civil liberties concern, and argue that it is as well met by narrowly defining racist speech as it is by other first amendment exceptions. We have already taken those first steps down the icy mountain, we have already abandoned the flat plane of absolutism. Cf. Schauer, Slippery Slopes, 99 HARv. L. REv. 
hatred laws, ${ }^{165}$ or the British experience, where censorship of racism is accompanied by censorship of political dissidents. If we outlaw the $\mathrm{Ku}$ Klux Klan as an organization repugnant to democratic values, then we can outlaw the Communist Party for the same reasons. Admitting one exception will lead to another, and yet another, until those in power are free to stifle opposition in the name of protecting democratic ideals.

A related and less persuasive argument is the fresh air position. This position suggests that the most effective way to control the Klan is to allow it to broadcast its ideas. When people are exposed to the hatred propagated by the Klan, they will reject it and organize against it. Suppressing the Klan will only force it to choose more violent and clandestine means of obtaining its goals. ${ }^{166}$

A corollary to the American position of protection of racist expression is that the government must take certain affirmative steps to preserve that right. ${ }^{167}$ The state must make public facilities available on a nondiscriminatory basis to individuals and groups wishing to express their race hatred. ${ }^{168}$ It must provide police protection to preserve order and protect speakers who are threatened by counter-demonstrators. ${ }^{169}$ Since groups like the Klan typically draw angry opposition when they parade in public streets, this has meant that the Klan is entitled to publicly financed police escorts. Without this, the right of

361 (1985) (discussing slippery slope arguments as logical fallacy. Professor Schauer points out that both sides in any legal argument can make slippery slope claims).

165. See Language as Violence, supra note 3, at 341 (in Windsor, Ontario, members of the French minority were prosecuted for publishing a mock anti-French pamphlet intended to show the absurdity of bigotry).

166. This position is in contradiction to the historical record: escalating racist speech always accompanies escalating racist violence. See, e.g., H. SHAPIRO, supra note 73. Where official and community condemnation of hate crimes is swift and vigorous, incidents tend to remain isolated. Where condemnation is not forthcoming, acts of hate tend to escalate. Cf. HATE Groups, supra note 38, at 6 (testimony of Anti-Defamation League of B'nai B'rith comparing the responses to fire bombings of East Haven and West Haven, Connecticut, concluding that to avoid repetition "[t]he people that conduct these kinds of acts must know that the community, the total community, does not support them, that they are pariahs").

167. T. EMERSON, supra note 159, at 627 (chapter entitled "Affirmative Promotion of Freedom of Expression").

168. Knights of the Ku Klux Klan v. East Baton Rouge Parish School Bd., 679 F.2d 64 (5th Cir. 1982) (school board thwarted in effort to stop KKK meeting in gym, but no fees awarded to KKK); Coen v. Harrison County School Bd., 638 F.2d 24 (5th Cir. 1981) (KKK granted permission to use public ball park; no fees against city); Collin v. Chicago Park Dist., 460 F.2d 746 (7th Cir. 1972) (first amendment right of access for Nazis to speak in public park).

169. See Collin v. Smith, 578 F.2d at 1209 ("the governmental interest ... could more narrowly be served by ... marshalling local, county, and state police to prevent violations"); $c$. Invisible Empire v. Mayor, 700 F. Supp. 281 (D. Md. 1988) (costs of police protection for KKK marchers must be borne by the town, not imposed on the marchers themselves); Invisible Empire Knights of the Ku Klux Klan v. City of W. Haven, 600 F. Supp. 1427, 1434 (D. Conn. 1985) (passing on the costs of police protection to marchers would amount to a "hecklers' veto"). 
free speech is meaningless. Angry and intolerant majorities could prevent unpopular minorities from using public facilities, rendering the right of free speech illusory.

The strong first amendment position outlined above represents certain values ${ }^{170}$ that are part of the American structure of government and the American commitment to political and civil rights. The American position may be extreme, but it responds to American circumstances. It recalls the times when our commitment to freedom was tested - the Sedition Act, the McCarthy era, the movement for racial justice, the riots and protests of the Vietnam age. Our commitment to the position has been neither steadfast nor universal. ${ }^{171}$ Judges have sometimes failed to understand it, resulting in loose doctrinal ends. ${ }^{172}$ The basic principle, however, has survived, and the thrust of the cases and commentary supports first amendment primacy.

The purpose of stating the strongest possible case for the American position is not merely to set the groundwork for an attack. The basic values of freedom of expression, while not provable in any natural law sense, are accepted by the international community. That the American commitment to the ideology of freedom has contributed to social progress and the limitation of repression is a part of our history. ${ }^{173}$ The question presented here is whether the values of the first amendment are in irresolvable conflict with the international movement toward elimination of racist hate propaganda, and whether any attempt to move United States law toward the international standard is worthwhile.

As a starting point in understanding what is really going on in the law of freedom of expression, it is helpful to note where the edges are.

170. Thomas Emerson, in his statement of the American position, identifies these values:

(1) Self-fulfillment, or the idea that each individual has the right to "his character and potentialities as a human being."

(2) Advancement of knowledge and discovery of truth, through free and vigorous exchange of a wide spectrum of ideas.

(3) Participation in political decisionmaking, which requires both access to knowledge and the right to express an opinion.

(4) Obtaining a stable community - by resolving conflict in the arena of open exchange of ideas. This promotes flexibility, gives everyone a stake in the process, and avoids the violent movement for change that would result from repression.

T. EMERSON, supra note 159, at 6-7.

171. See B. Schultz \& R. Schultz, It Did Happen Here: Recollections of PolitICAL REPRESSION IN AMERICA (1989).

172. For a laudable effort to conceptualize and clarify the underpinnings of existing doctrine, see Sunstein, supra note 66.

173. For cases close to home, see those upholding the free speech rights of lawyers, e.g., In re Sawyer, 360 U.S. 622 (1959) (lawyer reinstated after disbarment for vigorous protest against Smith Act trials). 
There are several forms of speech that are not entitled to the same protection that existing doctrine would afford racist propaganda.

In the area of commerce and industrial relations, expression is frequently limited. ${ }^{174}$ False statements about products, ${ }^{175}$ suggestions that prices be fixed, ${ }^{176}$ opinions about the value of stock, ${ }^{177}$ and proemployer propaganda during union elections, ${ }^{178}$ are all examples of expressions of ideas that are limited by the law. An instrumental analysis might be that smooth operation of the entities of commerce, and the need for a stable setting for the growth of capital, have overcome the commitment to civil liberties in these instances. A doctrinal first amendment explanation is that those are examples of hard cases, representing more than the expression of an idea. Some statements are noncommunicative acts, subject to legal restraint. ${ }^{179}$ Alternatively, some would argue that many existing exceptions are simply a mistake.

Speech and associational rights are limited in certain professional contexts. Government employees are forbidden from engaging in political activity to avoid problems of undue influence. ${ }^{180}$ Those charged with the public trust are asked to profess loyalty to the Constitution, ${ }^{181}$ and are asked to limit expression that will undermine their ability to do their job. ${ }^{182}$ The class of less-favored speakers has included, dubiously, children ${ }^{183}$ and prisoners. ${ }^{184}$ These exceptions sug-

174. See Schauer, Commercial Speech and the Architecture of the First Amendment, $56 \mathrm{U}$. CiN. L. REv. 1181 (1988) for the suggestion that the value of free speech is weakened by incremental decisionmaking on peripheral subjects such as commercial speech.

175. See Central Hudson Gas \& Elec. Corp. v. Public Serv. Commn., 447 U.S. 557, 566 (1980). See generally Note, Freedom of Expression in a Commercial Context, 78 HARV. L. REV. 1191 (1965) (false advertising); Note, Constitutional Realism: Legislative Bans on Tobacco Advertisements and the First Amendment, 1986 U. ILL. L. REV. 1193.

176. Sherman Anti-Trust Act, 15 U.S.C. $\$ 1$ (1982).

177. Securities Act of 1933 as amended, 15 U.S.C. $\$ \S 77 a-77 a a(1982$ \& Supp. 1989) (imposing liability for misleading statements in connection with the sale of securities).

178. Courts have recognized that in the labor context, employer speech can have a coercive effect upon employees who fear economic reprisal. Thus the employer's right to free speech is balanced against the employee's right to organize. See NLRB v. Gissel Packing Co., 395 U.S. 575 (1969) (applying 29 U.S.C. $§ 158$ ). A major premise of the national labor law scheme is that collective bargaining promotes labor peace and economic development.

179. Professor John Hart Ely has explored the difference between the restraint of acts and the restraint of communication, searching for the commmunicative elements of certain acts. Ely, Flag Desecration: A Case Study in the Roles of Categorization and Balancing in First Amendment Analysis, 88 HARV. L. REV. 1482 (1975). For elaboration of the content/act distinction, see Redish, The Content Distinction in First Amendment Analysis, 34 STAN. L. REv. 113 (1981).

180. See 5 U.S.C. $\S \S 1501-1508$ (1982) (regulating political activity of certain state and local employees); 5 U.S.C. $\$ \S 7321-7328$ (1982) (governing political activities of federal employees).

181. See, e.g., Knight v. Board of Regents, 269 F. Supp. 339 (S.D.N.Y. 1967), affd. per curiam, 390 U.S. 36 (1968).

182. See Cornelius v. NAACP Legal Defense \& Educ. Fund, Inc., 473 U.S. 788 (1985); Connick v. Myers, 461 U.S. 138 (1983).

183. See Hazelwood School Dist. v. Kuhlmeier, 484 U.S. 260 (1988) (censorship of student- 
gest that internal security and the functioning of government are other policies that override the first amendment in specific cases, to the legitimate discomfort of committed civil libertarians.

The override occurs again in the area of privacy and defamation. Expressing intimate and private facts about a private individual is subject to civil damages, as is the spread of untruths damaging to both public and private figures. ${ }^{185}$ First amendment protections are worked into the law of defamation and privacy, but they are not allowed to supersede completely the reputational interest and personal integrity of the victims of certain forms of expression. When courts are called into private disputes about defamatory speech, they are really mediating between competing interests of constitutional dimension: the right of expression, and the implicit right to a measure of personal integrity, peace of mind, and personhood.

Speech infringing on public order is another classic unprotected area. Bomb threats, incitements to riot, "fighting words," 186 and obscene phone calls are a few of the speech-crimes that slip through the first amendment's web of protection. These categories edge close to the category of racist speech. ${ }^{187}$ Under existing law, insults of such dimension that they bring men - this is a male-centered standard to blows are subject to a first amendment exception. ${ }^{188}$ The problem is that racist speech is so common that it is seen as part of the ordinary jostling and conflict people are expected to tolerate, rather than as fighting words. ${ }^{189}$ Another problem is that the effect of dehumanizing

run school newspaper allowed); Bethel School Dist. No. 403 v. Fraser, 478 U.S. 675 (1986) (censorship of sexual innuendo in student's campaign speech to a school assembly allowed).

184. See Thornburgh v. Abbott, 109 S. Ct. 1874 (censorship of incoming mail allowed); Pell v. Procunier, 417 U.S. 817, 822 (1974) ("a prison inmate retains those First Amendment rights that are not inconsistent with his status as a prisoner or with the penological objectives of the system").

185. See New York Times v. Sullivan, 376 U.S. 254 (1964) (limitation on defamation actions by public officials); Gertz v. Robert Welch, Inc., 418 U.S. 323 (1974) (defamation action by private figure); Virgil v. Time, Inc., 527 F.2d 1122 (9th Cir. 1975), cert. denied, 425 U.S. 998 (1976) (publication of true private facts).

186. See Chaplinsky v. New Hampshire, 315 U.S. 568 (1942) (limitation of speech and insults that provoke violence).

187. See Rabinowitz, Nazis in Skokie: Fighting Words or Heckler's Veto?, 28 DE PAUL L. REv. 259 (1979) (arguing that displaying swastika before individuals with known susceptibility to severe emotional distress because of past persecution falls within "fighting words" doctrine); see also Vietnamese Fishermen's Assn. v. Knights of the Ku Klux Klan, 543 F. Supp. 198 (S.D. Tex. 1982) (injunction against Klan demonstrations and paramilitary training designed to intimidate Vietnamese shrimpers falls within "fighting words" doctrine).

188. But see Cohen v. California, 403 U.S. 15 (1971).

189. See, e.g., Vaughn v. Pool Offshore Co., 683 F.2d 922 (5th Cir. 1982) (use of word $n-r$ and aggressive physical hazing and racist slurs were considered typical of offshore oil rig banter and "male interaction," and hence not violative of Title VII.) See also Howard v. National Cash Register Co., 388 F. Supp. 603, 606 (S.D. Ohio 1975) (listing racist slurs as part of the historical "language of the factory"). 
racist language is often flight rather than fight. ${ }^{190}$ Targets choose to avoid racist encounters whenever possible, internalizing the harm rather than escalating the conflict. Lack of a fight and admirable selfrestraint then defines the words as nonactionable. ${ }^{191}$ When racist leaflets threatening Representative Tyrone Brooks urged whites to band together to keep civil rights activists out of Rome, Georgia, state offcials felt that the first amendment prevented arrest because the leaflet "didn't threaten to kill anyone."192

While it is sometimes suggested that the first amendment is absolute, even strong civil libertarians are likely to admit that the absolutist view is unworkable. ${ }^{193}$ As Professor Frederick Schauer has pointed out, absolute protection of expression would render unconstitutional "all of contract law, most of antitrust law, and much of criminal law." 194 The need to distinguish protected from unprotected speech is inevitable.

If there are important competing interests represented in the international position on elimination of racist hate messages, if these interests are only met by limiting speech, and if the speech represented in racist hate propaganda is not the kind of speech most needful of protection, then it may be possible to remain true to the first amendment without protecting racist hate propaganda.

The following section will suggest that an explicit and narrow definition of racist hate messages will allow restriction while respecting first amendment values.

\section{NARRow ApPlication aNd Protection of First AMENDMENT VALUES}

This Article attempts to recognize and accommodate the civil libertarian position. The victim's perspective requires respect for the idea of rights, for it is those on the bottom who are most hurt by the absence of rights, and it is those on the bottom who have sustained the

190. Or, to deny it. See supra note 87.

191. As the draft comments to the Stanford University Fundamental Standard Interpretation on Free Expression and Discriminatory Harassment pointed out, it is unfair to use victims' disciplined practice of nonviolence or their demoralized, passive state as proof that insults are not "fighting words." Stanford University, Fundamental Standard Interpretation: Free Expression and Discriminatory Harassment 6 (Final Draft passed Apr. 12, 1989) [hereinafter Fundamental Standard] (on file with author).

192. HATE Group Activity, supra note 61, at 27.

193. For suggestion of an absolutist position, see New York Times v. Sullivan, 376 U.S. 254, 293-97 (1964) (Black, J., concurring).

194. Schauer, Categories and the First Amendment: A Play in Three Acts, 34 VAND. L. ReV. 265,270 (1981). 
struggle for rights in American history. 195 The image of book burnings should unnerve us and remind us to argue long and hard before selecting a class of speech to exclude from the public domain. ${ }^{196} \mathrm{I}$ am uncomfortable in making the suggestions made in this section if others fall too easily into agreement.

In order to respect first amendment values, a narrow definition of actionable racist speech is required. Racist speech is best treated as a sui generis category, presenting an idea so historically untenable, so dangerous, and so tied to perpetuation of violence and degradation of the very classes of human beings who are least equipped to respond that it is properly treated as outside the realm of protected discourse. ${ }^{197}$ The courts in the Skokie case ${ }^{198}$ expressed doubt that principles were available to single out racist speech for public limitation. This section attempts to construct a doctrinal and evidentiary world in which we might begin to draw the lines the Skokie courts could not imagine.

The alternative to recognizing racist speech as qualitatively different because of its content is to continue to stretch existing first amendment exceptions, such as the "fighting words" doctrine and the "content/conduct" distinction. ${ }^{199}$ This stretching ultimately weakens the first amendment fabric, creating neutral holes that remove protection for many forms of speech. Setting aside the worst forms of racist speech for special treatment is a non-neutral, value-laden approach that will better preserve free speech.

In order to distinguish the worst, paradigm example of racist hate messages from other forms of racist and nonracist speech, three identifying characteristics are suggested here:

1. The message is of racial inferiority;

2. The message is directed against a historically oppressed group; and

3. The message is persecutorial, hateful, and degrading.

195. For an elaboration of this point, see Matsuda, supra note 20, at 323.

196. Cf. Board of Educ. v. Pico, 457 U.S. 853, 879 (1982) (Blackmun, J., concurring) ("school officials may not remove books for the purpose of restricting access to the political ideas or social perspectives discussed in them").

197. Professor David Kretzmer has argued that racism is unique for two reasons: the "catastrophic historical experience" and the "universal formal condemnation." Kretzmer, supra note 36 , at 458.

198. Collin v. Smith, 447 F. Supp. 676 (N.D. Ill.), affd., 578 F.2d 1197 (7th Cir.), cert. denied, 439 U.S. 916 (1978); Village of Skokie v. National Socialist Party, 51 Ill. App. 3d 279, 366 N.E.2d 347 (1977), modified, 69 Ill. 2d 605, 373 N.E.2d 21 (1978).

199. See Vietnamese Fishermen's Assn. v. Knights of the Ku Klux Klan, 543 F. Supp. 198, 208 (1982) (using "conduct" and "fighting words" distinctions to limit Klan activity). 
Making each element a prerequisite to prosecution prevents opening of the dreaded floodgates of censorship.

The first element is the primary identifier of racist speech: racist speech proclaims racial inferiority and denies the personhood of target group members. All members of the target group are at once considered alike and inferior.

The second element attempts to further define racism by recognizing the connection of racism to power and subordination. Racism is more than race hatred or prejudice. It is the structural subordination of a group based on an idea of racial inferiority. Racist speech is particularly harmful because it is a mechanism of subordination, reinforcing a historical vertical relationship.

The final element is related to the "fighting words" idea. The language used in the worst form of racist speech is langauge that is, and is intended as, persecutorial, hateful, and degrading.

Part VII, below, applies these three elements to hypothetical cases. Using these elements narrows the field of interference with speech. ${ }^{200}$ Under these narrowing elements, arguing that particular groups are genetically superior in a context free of hatefulness and without the endorsement of persecution is permissible. Satire and stereotyping that avoids persecutorial language remains protected. Hateful verbal attacks upon dominant-group members by victims is permissible. These kinds of speech are offensive, but they are, in respect of first amendment principles, best subjected to the marketplace of ideas. This is not to suggest that we remain silent in the face of offensive speech of this type. Rather, the range of private remedies - including counter-speech, social approbation, boycott, and persuasion should apply.201

If the most egregious, paradigmatic racial hate messages are not properly left to private remedy, it is important to explain why. One way to explain this is to consider the difference between racist hate

200. Another narrowing device is an intent test. The requisite intent suggested under this scheme is an intent to speak to an audience - "publication" in the common law scheme - and actual or imputed - "should have known" - knowledge of the offensive character of the words. Others have suggested broader definitions of racist speech, using "intent to defame" as the test. See Lasson, supra note 147, at 126. Narrow and clear definition is consistent with the overbreadth doctrine: any rule that prohibits unprotected speech but that could also prohibit protected speech is unconstitutional. See, e.g., Gooding v. Wilson, 405 U.S. 518, 520-21 (1972).

201. The ability to discuss and deal privately with some forms of offensive language is shown in a recent exchange between B'nai B'rith International and the American-Arab Anti Discrimination Committee ("ADC"). The ADC objected to a fundraising letter that alleged that "Arab money is pouring into college campuses" and that "the Arab presence... is poisoning the minds of our young people." B'nai B'rith Apologizes for Letter Containing Anti-Arab Statements, N.Y. Times, Feb. 10, 1989, at 14, col. 4. Letters of protest from the ADC, New Jewish Agenda, and various church groups resulted in withdrawal of the offensive letters. Id. 
messages and Marxist speech. Marxist speech is the kind of unpopular political expression the first amendment is intended to protect. Marxist speech is, according to a once prevalent view, the advocacy of overthrow of existing governments, inevitably leading to dictatorships and persecution of dissidents and capitalists. It is thus, it was argued, dangerous speech, properly censored. The legacy of this view was McCarthyism and the shattered lives of hundreds of decent citizens. ${ }^{202}$

How can one argue for censorship of racist hate messages without encouraging a revival of McCarthyism? There is an important difference that comes from human experience, our only source of collective knowledge. We know, from our collective historical knowledge, that slavery was wrong. We know the unspeakable horror of the holocaust was wrong. We know white minority rule in South Africa is wrong. This knowledge is reflected in the universal acceptance of the wrongness of the doctrine of racial supremacy. There is no nation left on this planet that submits as its national self-expression the view that Hitler was right. ${ }^{203}$ South Africa is alone ${ }^{204}$ in its official policy of apartheid, and even South Africa, in making its case to the world community, is careful to avoid an explicit ideology of racial supremacy, preferring instead the rhetoric of one-step-at-a-time. At the universities, at the centers of knowledge of the international community, the doctrines of racial supremacy and racial hatred are again uniformly rejected. At the United Nations the same is true. We have fought wars and spilled blood to establish the universal acceptance of this principle. The universality of the principle, in a world bereft of agreement on many things, is a mark of collective human progress. The victim's perspective, one mindful of the lessons of history, thus accepts racist speech as sui generis and universally condemned.

Marxist speech, on the other hand, is not universally condemned. Marxism presents a philosophy for political organization, distribution of wealth and power, ordering of values, and promotion of social change. By its very content it is political speech going to the core of ongoing political debate. Many nations adhere to Marxist ideology, and it is impossible to achieve world consensus either for or against

202. See E. Schrecker, No IVORY TOWER: MCCARThyiSM AND THE UNIVERSITIES (1986). For a moving account of the effects of McCarthyism on one family, see K. CHERNIN, IN MY MOTHER's HouSE (1983).

203. The uniform rejection of racist ideology is evidence of moral truth. I suggest more than an opinion poll test. I suggest as well that the doctrine of racial supremacy is wrong, both morally and factually, and that the consensus of human opinion helps us to know this.

204. Cf. Derrida, Racism's Last Word, Harper's, Feb. 1986, at 21, 22 (the word "apartheid" described as "the death rattle of what is already an interminable agony, something like the setting in the West of racism"). 
this view. Marxists teach in universities. While Marxist ideas are rejected and abhorred by many, Marxist thought, like liberal thought, neoconservative economic theory, and other conflicting structures for understanding life and politics, is part of the ongoing efforts of human beings to understand their world and improve life in it.

What is argued here, then, is that we accept certain principles as the shared historical legacy of the world community. Racial supremacy is one of the ideas we have collectively and internationally considered and rejected. As an idea connected to continuing racism and degradation of minority groups, it causes real harm to its victims. We are not safe when these violent words are among us.

Treating racist speech as sui generis and universally condemned on the basis of its content and the harmful effect of its content is precisely the censorship that civil libertarians fear. I would argue, however, that explicit content-based rejection of narrowly defined racist speech is more protective of civil liberties than the competing-interests tests or the likely-to-incite-violence tests that can spill over to censor forms of political speech. ${ }^{205}$

Looking again to the emerging outsider jurisprudence, I derive basic principles: the need to fight racism at all levels, the value of explicit formal rules, and a fear of tyranny. These principles suggest the wisdom of legal intervention with only a narrowly defined class of racist hate propaganda. ${ }^{206}$

A range of legal interventions, including the use of tort law and criminal law principles, is appropriate to combat racist hate propaganda. ${ }^{207}$ While the value of free speech can guide the choice of procedure - including evidentiary rules and burdens of persuasion - it

205. Courts have rejected statutes that cast too wide a net over forms of expression. See, e.g., Terminiello v. Chicago, 337 U.S. 1 (1949) (city ordinance banning speech that brings about unrest is over-broad).

206. Examples of the kind of over-broad statutes drafted to avoid regulation of racist content include "secret society" laws. See, e.g., New York ex rel. Bryant v. Zimmerman, 278 U.S. 63 (1928) (upholding a state law requiring all organizations to register and submit membership lists to the state, as used against KKK membership).

207. In addition to judicial modification of first amendment analysis, the forms of remedy could include creation of a new crime of racist speech, enhanced sentencing for existing crimes where racial motivation is found, administrative mechanisms for fines and injunctive relief, civil actions for damages, or a combination of the above. Compare CAL. CIV. CODE $\$ 51.7$ (West 1989) (civil remedies for violence motivated by racial hatred) and CAL. CIV. CODE $\S 52.1$ (West 1989) (remedies for deprivation of rights motivated by racial hatred) and CAL. PENAL CoDE $\$ \S 422.6-.9$ (West 1988) (criminal penalties for deprivation of rights because of race) and CAL. PENAL CODE $\S 1170.75$ (West 1988) (racial animus an aggravating factor in felony sentencing) with OHIO REv. CODE ANN. \$2927.12 (Baldwin 1989) (creating a crime of "ethnic intimidation" for violent and property crimes committed because of race) and WIS. STAT. ANN. $\S 939.645$ (West Supp. 1988) (raising penalties for crimes committed because of race) and Wis. STAT. ANN. $\$ 943.012$ (West Supp. 1988) (creating crime for damaging religous property). 
should not completely remove recourse to the institution of law to combat racist speech. Racism as an acquired set of behaviors can be dis-acquired, ${ }^{208}$ and law is the means by which the state typically provides incentives for changes in behavior.

\section{HARD CASES}

In order to get beyond racism, we must first take account of race. There is no other way. ${ }^{209}$

Of course I emphasize different things, Doctor, because history has treated my people differently from yours. ${ }^{210}$

This section will consider stories at the edge, a tentative discussion of problem cases that may arise under the definition of actionable racist speech discussed here. The connecting thread in these examples is the need for clarity about the historical context in which racist speech arises, and attention to the degree of harm experienced by targets of different kinds of racist speech.

\section{A. A Case of the Angry Nationalist}

Expressions of hatred, revulsion, and anger directed against historically dominant-group members by subordinated-group members are not criminalized by the definition of racist hate messages used here. Malcolm X's "white devil" statements - which he later retracted are an example.211 Some would find this troublesome, arguing that any attack on any person's ethnicity is harmful. The harm and hurt is there, but it is of a different degree. Because the attack is not tied to the perpetuation of racist vertical relationships, it is not the paradigm worst example of hate propaganda. The dominant-group member hurt by conflict with the angry nationalist is more likely to have access to a safe harbor of exclusive dominant-group interactions. Retreat and reaffirmation of personhood are more easily attained for historically non-subjugated-group members.

While white-hating nationalist expressions are troublesome both politically and personally, I would interpret an angry, hateful poem by

208. See W. SEDlacex \& G. Brooks, supra note 68 , at 8-10.

209. Regents of the Univ. v. Bakke, 438 U.S. 265, 407 (1978) (Blackmun, J., dissenting).

210. Delgado, Derrick Bell and the Ideology of Racial Reform: Will We Ever Be Saved? (Review Essay), 97 YALE L.J. 923, 937 (1988).

211. Malcolm X, The Autobiography of Malcolm X 251-52, 363 (1966); see also Gannon v. Action, 303 F. Supp. 1240 (E.D. Mo. 1969) (African-American activists interrupt church services with taunts against "white Christian racists"); HATE GRoup ACriviTY, supra note 61, at 17 (report of Iman Pilamen El Amin, Social Iman of the Atlanta Muslim Mission, describing the evolution of the American Muslim Mission since its 1975 adoption of the ideology of the oneness of all humanity, and abandonment of the white devil idea). 
a person from a historically subjugated group ${ }^{212}$ as a victim's struggle for self-identity in response to racism. ${ }^{213}$ It is tied to the structural domination of another group. ${ }^{214}$ Part of the special harm of racist speech is that it works in concert with other racist tools to keep victim groups in an inferior position. ${ }^{215}$ Should history change course, placing former victim groups in a dominant or equalized position, the newly equalized group will lose the special protection suggested here for expression of nationalist anger.

Critics of this proposal ask how one knows who is oppressed and who isn't. Poor whites, ethnic whites, wealthy ethnics - the confusing examples and barriers to classification abound. The larger question is how anyone knows anything in life or in law. To conceptualize a condition called subordination is a legitimate alternative to denying that such a condition exists. ${ }^{216}$ In law, we conceptualize. We take on mammoth tasks of discovery and knowing. We can determine when subordination exists by looking at social indicators: wealth, mobility, comfort, health, and survival tend to mark the rise to the top and fall to the depths. ${ }^{217}$ The rise and fall of group status is relevant even when an individual is a counterexample, because when the group is subordinated, even the lucky counterexample feels the downward

212. See, e.g., Trask, racist white woman, BAMBOO RIDGE, Fall 1987, at 86.

213. Nationalism may be an interim stage on the path to egalitarian vision. See Sizemore, Separatism: A Reality Approach to Inclusion, in RACIAL CRISIS IN AMERICAN EduCATION 249 (R. Green ed. 1969).

214. In an analogous context, the work of Catharine MacKinnon recognizes subordination of women and calls for laws addressing that subordination. See, e.g., C. MacKinnon, SEXUAL HARASSMENT OF WORKING WOMEN (1979). Christine Littleton points out that the subordination approach differs significantly from the inequality approach. Inequality calls for equal treatment. Subordination calls for an uplifting of women from a degraded status. See Littleton, supra note 31 , at 768 .

215. An understanding of relative power is implicit in Beauharnais v. Illinois, 343 U.S. 250, 252 (1952) (allowing action against pamphlet calling for the "white people in Chicago to unite" against becoming "mongrelized" and against "the aggressions . . . rapes, robberies, knives, guns and marijuana of the negro") (omission in original), in Brown v. Board of Educ., 347 U.S. 483 (1954) (recognizing that segregation carries a message of African-American inferiority), and in New York Times v. Sullivan, 376 U.S. 254, 293-97 (1964) (Black, J., concurring) (speech rights of African-American civil rights protesters upheld against libel action by white sheriff). These cases, decided against a subtext of racial subordination, reveal the Court struggling to design neutral rules to deal with a decidedly unequal context, and siding with the subordinated group in each case. Justice Black in his Beauharnais dissent warned that the Court was taking a step toward censorship of legitimate social protest including protest by minorities. New York Times is, in a sense, a rejoinder to Justice Black.

216. Cf. Colker, Anti-Subordination Above All: Sex, Race, and Equal Protection, 61 N.Y.U. L. REV. 1003 (1986) (arguing for primacy of antisubordination principle over a neutral equality principle).

217. See, e.g., Delgado, supra note 210 , at $938-41 \&$ nn.88-111 (documenting statistical and historical evidence of subordination of nonwhites); Scales-Trent, supra note 17 (documenting degraded social status of African-American women). 
tug. ${ }^{218}$ Luck is not the same as privilege.

In some cases, a group's social well-being may improve, while their victimization continues. Asians who experience economic success are often underemployed relative to their talents. ${ }^{219}$ Jews who attain equality in employment still experience anti-Semitic vilification, harassment, and exclusion. ${ }^{220}$ Catholics are relatively free from discrimination in some communities, and subject to vile bigotry in others. ${ }^{221}$ Evidence of the relative subjugation of various groups is available to factfinders. ${ }^{222}$

In the same way that lawyers martial evidence in an adversarial setting to find facts in other areas of law, we can learn to do the same to know the facts about subordination, and to determine when hate speech is used as an instrument of that subordination. ${ }^{223}$

\section{B. First Variation: Anti-Semitism and Racism by Non-Whites}

What of hateful racist and anti-Semitic speech by non-whites? The phenomena of one subordinated group inflicting racist speech upon another subordinated group is a persistent and touchy problem. Similarly, members of a subordinated group sometimes direct racist language at their own group. The victim's privilege becomes problematic when it is used by one subordinated person to lash out at another. While I have argued here for tolerance of hateful speech that comes from an experience of oppression, when that speech is used to attack a subordinated-group member, using language of persecution, and

218. Minority law professors, typically privileged by class and education, still trade story after story of police harassment, racist insult, and white hostility. R. DELGADO, MINORITY LaW Professors' Lives: The Bell-Delgado Survey (Institute for Legal Studies Working Papers Series 3:9, 1988); $c f$. Fiss, Groups and the Equal Protection Clause, 5 PHIL. \& PuB. AfF. $107,148-49$ (1976) (well-being and status of individuals is related to the status of the individual's group).

219. See Kim \& Hurh, Korean Americans and the "Success" Image: A Critique, AMERASIA J., Fall/Winter 1983, at 3.

220. See, e.g., HATE GROUP ACTIVITY, supra note 61, at 13 (noting several instances of threats and attacks directed at Jews in Georgia including cross burnings, synagogue vandalism, bomb threats, and regular harassment of congregations leaving worship - including a car veering off the road to threaten teenagers leaving services, BB gun shooting at Passover, and verbal taunts such as "Hitler still lives").

221. See id. at 17 (noting resurgence of anti-Catholic bigotry in Georgia).

222. For an argument that African-American women require heightened legal protection beyond that of white women or African-American men because of the historical circumstances of their two statuses that "have often combined in ways which are not only additive, but synergistic - that is, they create a condition for black women which is more terrible than the sum of their two constituent parts," see Scales-Trent, supra note 17, at 9.

223. See HATE Group ACTIVITY, supra note 61, for an example of a formal effort to amass testimony on the reality of racism in one locality. 
adopting a rhetoric of racial inferiority, I am inclined to prohibit such speech.

History and context are important in this case because the custom in a particular subordinated community may tolerate racial insults as a form of word play. ${ }^{224}$ Where this is the case, community members tend to have a clear sense of what is racially degrading and what is not. The appropriate standard in determining whether language is persecutorial, hateful, and degrading is the recipient's community standard. We should avoid further victimization of subordinated groups by misunderstanding their linguistic and cultural norms.

\section{Second Variation: Zionism}

I reject the sweeping charge that Zionism is racism and argue instead for a highly contextualized consideration of Zionist speech. To the extent any racial hostility expressed within a Zionist context is a reaction to historical persecution, it is protected under the doctrinal scheme suggested in this Article. Should white Zionists ever lose the victim's privilege? If Zionist speakers are white, do hateful, racebound expressions of theirs necessarily reinforce historical conditions of white dominance over brown and black people? The analysis must turn on the particular context. If a Zionist's expression of anger includes a statement of generic white supremacy and persecution, the speaker chooses to ally with a larger, historically dominant group, and the victim's privilege should not apply. On the other hand, angry, survivalist expression, arising out of the Jewish experience of persecution and without resort to the rhetoric of generic white supremacy, is protected under the contextualized approach. Again, it is important to add that the various subordinated communities are best equipped to analyze and condemn hate speech arising within their midst. ${ }^{225}$

\section{The Case of the Dead-Wrong Social Scientist}

Another difficult case is that of the social scientist who makes a case for racial inferiority in an academic setting based on what is presented as scientific evidence. Various theories of genetic predisposition to violence, cultural lag, and race/intelligence correlation fall into this category. ${ }^{226}$ Critics note that these pseudo-scientific, Eurocentric

224. See, e.g., C. Stack, All OuR KIN 16 (1974) (discussing acceptable racial teasing between African-American informants and a white anthropologist).

225. I thus defer to the evolving judgment of the American and Israeli Jews and seek dialogue with them on statements emerging from the Israeli far right. Cf. Racism from the Right, NEwSWEEK, Sept. 3, 1984, at 44 (quoting Meir Kahane as stating, "I don't want to lose my country to Arab bullets or Arab babies" to supporters' shouts of "Death to Arabs!").

226. See, e.g., Jensen, How Much Can We Boost IQ and Scholastic Achievement?, 5 HARV. 
theories are racist and ignorant. ${ }^{227}$ This raises two separate questions. First, should such views receive an audience and a forum in an academic setting? Second, should we criminalize expressions of such views?

As to the first question, the answer may well be no. Not all views deserve the dignity of an academic forum. Poorly documented, racially biased work does not meet the professional standards required of academic writing. If a writer manages to come up with a theory of racial inferiority supported by credible evidence, that theory may deserve a forum. Under the principle of academic freedom, ignorant views need not be heard, but unpopular academically tenable views should be.

As to the second question, outlawing this type of speech might be inappropriate. ${ }^{228}$ Assuming the dead-wrong social-science theory of inferiority is free of any message of hatred and persecution, the ordinary, private solution is sufficient: attack such theories with open public debate, and with denial of a forum if the work is unsound in its documentation.

\section{E. The Case of Wordless Speech: Symbols and Regalia, Text and Context}

There are certain symbols and regalia that in the context of history carry a clear message of racial supremacy, hatred, persecution, and degradation of certain groups. ${ }^{229}$ The swastika, the Klan robes, the burning cross are examples of signs - like all signs - that have no meaning on their own, but that convey a powerful message to both the

EDuc. REV. 1 (1969) (concluding that African Americans' lower IQ scores are due, in part, to genetic factors). But see S. Gould, The Mismeasure of MAN (1981) (crtiquing various pseudo-scientific claims of racial superiority).

227. See A Theory Goes On Trial, TimE, Sept. 24, 1984, at 62 (Dr. Shockley, who admits subscribing to the white supremacist publication "Thunderbolt," is called "nearly incompetent" by trained geneticist).

228. Compare Lasson, supra note 147, at 127 (arguing for restraint of Shockley's conclusions) with Note, Group Vilification Reconsidered, 89 YALE L.J. 308 (1978) (suggesting revival of group defamation doctrine but arguing that statements of opinion, such as Shockley's, should be protected). The Yale Note is an attempt to penalize a limited class of racist speech, using common law principles such as the fact-opinion distinction, obloquy, and prurient interest. Such tests are tailored to the problems of obscenity and defamation, and do not adequately, in this author's opinion, confront the complexity of racist speech.

229. See Danon, The Illinois Supreme Court and the Appellate Decisions Regarding Prior Restraint, in Skokie v. The American Nazi Party, 67 ILL. B.J. 540, 541 (1979) (arguing that patterning conduct, uniform, slogan, and language after German Nazi Party "is equivalent of encouragement to identify with the genocide of the Jews and an indirect incitement to follow Hitler's 'final solution' "); Lasson, supra note 147, at 127 (arguing for limitation of swastika displays on a group libel theory). 
user and the recipient of the sign in context. ${ }^{230}$

Here we must look to the history of these signs to understand what they mean. If the historical message, known to both victim and perpetrator, is racist persecution, then the sign is properly treated as actionable racist speech. ${ }^{231}$

\section{F. The Cold Version of the Classic Forms of Anti-Semitism}

Anti-Semitic literature is one of the most highly developed and despicable forms of hate propaganda. A significant problem with the test proposed here is that it may, at first blush, seem too narrow to cover some chillingly sterile brands of anti-Semitic literature. The monetary conspiracy theories, the tales of mysterious cartels, the revisionist histories distributed by anti-Semitic hate groups are sometimes cunningly devoid of explicit hate language. ${ }^{232}$ Here is another story:

One recent summer, after giving a talk advocating restriction of hate speech, I was dutifully catching up on reading of academic junk mail newsletters, book announcements, requests for contributions. I picked up a leaflet, professionally printed and attributed to an academic institution, and began reading what looked like a mildly interesting historical essay. It was only after several paragraphs that I realized I was reading a holocaust hoax tract. My heart started racing as soon as I realized what a horrible thing $I$ held in my hand. I felt fear and revulsion that I was targeted to receive this mail, and that it was written in such a way that I didn't immediately recognize it for what it was. I fished in the rubbish can for the envelope and found it had no return address - that should have been the tip-off. The California postmark gave me some relief. At least the writers were not in my immediate neighborhood. The fear, however, remains, and I am more cautious about where and to whom I will speak on this topic that brings hate to my desk.

I am inclined to criminalize the cold-blooded version of antiSemitic literature. Given the historical record, this "cold" version is just as hateful, for all its tone of distorted rationality, as the "hot" name-calling versions. To call the holocaust a myth is to defame the

230. See National Alliance Against Racist and Political Repression, Draft Legislation to Stop Racist Hate Group Activity, 44 GuILD PrAc. 131 (1987) (recognizing that white-hooded robes and masks, burning crosses, and swastikas are associated with acts of violence, and suggesting criminal and civil penalties for their use).

231. See, e.g., MD. ANN. CODE of 1957 art. 27, $\S 10$ A (1987) (prohibition of cross burning without notice to authorities).

232. Cf. Taylor v. Canada, 4 HUM. RTs. L.J. 193 (UN-Hum. Rts. Comm. 1983) (prosecution under Canadian law for recorded telephone message alleging that Jewish conspiracy would lead to financial collapse allowed); see also CIVIL RIGHTS Division, ANTI-DEFAMATION LEAGUE of B'NAI B'RITH, SPECIAL EdiTION: THE LiberTY LOBBY NETWORK (1987) (analyzing pseudointellectual anti-Semitic groups); Note, supra note 228, at $331 \&$ n.106 (discussing the Protocols of the Learned Elders of Zion, "a classic of anti-Semitic literature"). 
dead, as Elie Wiesel has so eloquently put it. ${ }^{233}$ It is a deep harm to the living. In a range of different contexts, the common law has recognized the likelihood of emotional harm to the living from carelessness in treatment of the dead. ${ }^{234}$

The element of hatred and degradation is present in the monetary conspiracy theory and holocaust hoax literature. Like the swastika, these texts take their hateful meaning from their historical context and connection to violence. To anyone who knows that context they cause legitimate distress.

\section{G. Collections, Museums, Neutral Reportage, Humor, and Literary Realism}

YES! Send me The SS, to examine for 10 days free, as my introduction to THE THIRD REICH. ${ }^{235}$

There are instances in which hate propaganda is deliberately spread by persons who are not themselves hatemongers. There are groups that preserve and disseminate hate propaganda for the purpose of educating the public of the evils of racism and anti-Semitism. ${ }^{236}$ There are groups and individuals who collect racist memorabilia for reasons of collectability, sometimes also claiming an educative function, and other times for reasons of fondness for ephemeras of evil. There are news reporters who repeat racist speech in order to report the news of its utterance, law professors who repeat racist words in hypotheticals for class discussion of the first amendment. In these cases the hate message is spread for purposes other than persecution. The hateful message is once removed from direct transmission by a buffer zone of a nonpersecuting presenter.

233. Address by Elie Wiesel, Hofstra University Conference on Group Defamation and Freedom of Speech (Apr. 20, 1988).

234. See, e.g., Kirker v. Orange County, 519 So. $2 d 682$ (Fla. Dist. Ct. App. 1988) (cause of action against medical examiner for removing body parts without survivor's permission); Ingaglio v. Kraeer Funeral Home, Inc., 515 So. 2d 428 (Fla. Dist. Ct. App. 1987) (cause of action for emotional distress for malicious mishandling of deceased husband's remains); The Neptune Society Cases, 31 ATLA L. Rep. 223 (Sacramento County Super. Ct., Feb. 22, 1988) (settlement for failure to properly cremate and scatter remains as promised).

Desecration of graves and memorials is a common tactic of hate groups. See, e.g., ATTORNEY GENERAL's REPORT, supra note 47 , at 44 (desecration of memorial to a murdered Vietnamese youth in Davis, California); HATE Group ACTIVITY, supra note 61, at 14 (spray painting of Martin Luther King, Jr., crypt); HATE GrouPS, supra note 38, at 4 (in Connecticut, a statue of Martin Luther King, Jr., and a Holocaust memorial were defaced).

235. From a clip-out coupon in a two-page advertisement for a Time-Life book series, SPORTS ILLUSTRATED, Feb. 6, 1989, at 42-43. The ad included portraits of S.S. figures and a smail, color highlighted swastika in the lower left-hand corner. It in no way suggested approval of S.S. activities, although it did make me uneasy in its tone of fascination.

236. See Simon Wiesenthal CENTER, Response, supra note 58, at 4-5 (reprinting an antiSemitic cartoon and slurs for informational purposes). 
When I viewed an Anti-Defamation League display of Nazi propaganda, I felt a familiar, queasy revulsion - the same feeling I got when I viewed dusty spoils of war, emblazoned with swastikas, at the veterans' halls I visited with my father as a child. What I did not feel was the heart-racing fear engendered by hate propaganda from anonymous senders. Knowing the intent of the Anti-Defamation League made the presentation less intrusive. Knowing that the League is in constant dialogue with victim-group members, carefully considering the possible harms of neutral presentations of hate propaganda, was comforting on the intellectual level.

The growing passion for collecting racist memorabilia is more troublesome. ${ }^{237}$ Not all collectors are involved in careful debate, weighing the harm of insult against the value of historic preservation. State intervention might be appropriate where collectors' displays cause gratuitous harm to viewers. The key to differentiating between the Anti-Defamation League display and a hypothetical Gestapo Collector's Club display of lovingly polished storm-trooper paraphernalia is the victim's story. Rather than looking to the neutral, objective, unknowing, and ahistorical reasonable person, we should look to the victim-group members to tell us whether the harm is real harm to real people.

Another area of seemingly less egregious speech is humor. ${ }^{238}$ Consider this comment by an American judge: "Do you know how to make a [ethnic group] omelette? Well, first you have to go out and steal three eggs."239 Not only are these jokes unfunny, they are also cruel and hurtful in much the same way that racist epithets are. ${ }^{240}$

237. In visiting an antique shop in Charleston, South Carolina, I noticed old Jim Crow signs for sale as collectors items and wondered who collected the signs, and for what reasons. The demand by collectors for such items is evidenced by ads in antique traders' magazines.

Household items depicting African Americans in servile and degraded positions were common from 1890 to the 1950s. See Dubin, Symbolic Slavery: Black Representations in Popular Culture, 34 Soc. ProBs. 122 (1987). Dubin catalogs a disgusting array of such items. Some such items include violent imagery intended as humor, such as children eaten by alligators, and golf tees driven into human heads. Dubin argues that popular culture does symbolic violence, implemented when other forms of control, such as slavery, are eliminated. Dubin uses the concept of cultural capital to explain how such items keep certain groups in subordinated positions.

238. See State Div. of Human Rights v. McHarris Gift Center, 52 N.Y.2d 813, 418 N.E.2d 393, 436 N.Y.S.2d 878 (1980), affg. 71 A.D.2d 813, 419 N.Y.S.2d 405 (1979) (ruling that display of Polish joke items does not deny equal access to stores to people of Polish descent).

239. Statement of a judge handling a farm worker's case, reported in Judge Bradshaw: Bad Humor Man, FoOD AND JUSTICE, Apr., 1988, at 8 (a publication of the United Farm Workers).

240. For dissents recognizing the harm of racist jokes, see McHarris Gift Center, 52 N.Y.2d at $814,816,418$ N.E.2d at 393, 394 (Cooke, C.J., and Jansen, J., separately dissenting) (both arguing that Polish gag gifts infringe on free enjoyment of public accommodations). See also Racist and Sexist Jokes: How Bad Are They (Really)?, RePORT From THE CENTER For PhILOSOPHY \& PUBLIC POLICY, Spring/Summer 1987, at 9, 11 (discussing the forced resignations of Earl Butz and James Watt for telling racist jokes and noting that "[t]he distinctive wrong of 
That they are said with a smile, and in a context that is socially understood as a somewhat more appropriate venue for insult, changes their character somewhat. It is a venue in which private sanction ${ }^{241}$ has some opportunity for success. The comedian Richard Pryor, for example, has stated publicly that he has been persuaded to discontinue comedic use of a racial epithet in his performances. ${ }^{242}$

Similarly, in considering the use of racist slurs in the interests of realism in books, films, and theater, the experience of victim-group members is a guide. Writer-Director Spike Lee's recent film Do the Right Thing 243 contains a rapid-fire sequence of racial epithets spoken by characters from different racial groups in a Brooklyn neighborhood. The hyper-realism of the sequence offers an incisive anti-racist critique of racist speech. Similarly, Mark Twain, known as a great American writer and anti-racist, used racist dialogue to portray a racist land. The problem for some African-American parents is that their young children may suffer harm from further exposure to racist language, particularly in a white majority setting. There is a danger of some of the students missing entirely, as one commentator noted, ${ }^{244}$ the ironic message and simply enjoying a racist dialogue on its face.

The failure of school integration and the under-representation of African Americans in positions of authority in the schools increases the danger that Mark Twain's realism, in some schools, will cause the kind of harm Twain himself would have abhorred. We need safe harbors before we begin rocking boats.

Consider this story:

A white teacher in Gould, Arkansas, resigned in tears after parental protests over her statement to boisterous school children that, "I think you're trying to make me think you're a bunch of poor, dumb n—rs, and I don't think that." Seats on the school board and other positions of authority in that town of sixty percent African-American residency, were occupied by African Americans. Students signed petitions urging the school board to reconsider its actions against the teacher, and to give her a second chance. The teacher was reinstated, expressing sincere regret for her error, and her thanks to the students for a second chance. A picture of the smiling white teacher, embracing an African-American student leader,

racist and sexist jokes is that the stereotype they evoke and help to maintain are so deeply implicated in our society's long history of injustice to disadvantaged groups").

241. The attorney for the United Farm Workers who heard the joke, supra note 239, responded, "I don't find ethnic jokes humorous. I don't tell them and I don't like to hear them." Judge Bradshaw: Bad Humor Man, supra note 239.

242. Statement of Richard Pryor, in Live on the Sunset Strip (Columbia Pictures 1982).

243. Do the Right Thing (Universal Pictures 1989).

244. Marx, Huck at 100, 241 NATION 150 (1985). 
accompanies the news item. ${ }^{245}$

Would that all incidents of hate speech have that ending: victims empowered, consciousness raised, community restored, harm kept at bay. Unfortunately for most of us, the conditions necessary for the result achieved in that small Arkansas town are not the conditions we live under. The harm of racist speech slices deeper, the farther away we are from such a life.

\section{H. The Special Case of Universities}

A marked rise of racial harassment, hate speech, and racially motivated violence marks our entry into the 1990 s. $^{246}$ The epidemic of racist incidents on university campuses is a disturbing example of this. ${ }^{247}$ The application of the first amendment to racist speech, once discussed hypothetically in law schools, is now debated in classrooms where hate messages have actually appeared. ${ }^{248}$ The next round of judicial opinions tangling with hate speech and the first amendment may well come from the universities.

University administrators at public institutions are bound by the first amendment under state action doctrine. At private institutions, the principle of free speech is often evoked as a matter of ethics, regardless of whether the Constitution applies directly. The university case raises unique concerns. Universities are special places, charged with pedagogy, and duty-bound to a constituency with special vulnerabilities. Many of the new adults who come to live and study at the major universities are away from home for the first time, and at a vulnerable stage of psychological development. ${ }^{249}$ Students are particu1.

245. Black Students Forgive Teacher's Mistaken Slur, N.Y. Times, Oct. 17, 1988, at 17, col.

246. See, e.g., Anti-Semitic Incidents in 1988 Put at a 5-Year High, N.Y. Times, Jan. 29, 1989 , at 20 , col. 1 .

247. See supra note 71.

248. I heard reports of racist slurs appearing on blackboards at the State University of New York at Buffalo. To its credit, the School of Law issued a statement from the faculty warning that sanctions will be imposed for "racist, sexist, homophobic and anti-lesbian, ageist, and ethnically derogatory statements" that indicate the student lacks "sufficient moral character to be admitted to the practice of law." Faculty Statement Regarding Intellectual Freedom, Tolerance, and Prohibited Harassment, State University of New York at Buffalo School of Law, Oct. 3, 1987.

249. The typical university student is emotionally vulnerable for several reasons. College is a time of emancipation from a pre-existing home or community, of development of identity, of dependence-independence conflict, of major decision making, and formulation of future plans. The move to coilege often involves geographic relocation - a major life-stress event - and the forging of new peer ties to replace old ones. All of these stresses and changes render the college years critical in development of one's outlook on life. College students experiment with different passions, identities, and risks. A negative environmental response during this period of experimentation could mar for life an individual's ability to remain open, creative, and risk-taking. I 
larly dependent on the university for community, for intellectual development, and for self-definition. Official tolerance of racist speech in this setting is more harmful than generalized tolerance in the community-at-large. It is harmful to student perpetrators in that it is a lesson in getting-away-with-it that will have lifelong repercussions. It is harmful to targets, who perceive the university as taking sides through inaction, and who are left to their own resources in coping with the damage wrought. ${ }^{250}$ Finally, it is a harm to the goals of inclusion, education, development of knowledge, and ethics that universities exist and stand for. ${ }^{251}$ Lessons of cynicism and hate replace lessons in critical thought and inquiry.

The campus free speech issues of the Vietnam era, ${ }^{252}$ and those evoked by the anti-apartheid movement, pit students against university administrators, multinational corporations, the U.S. military, and established governments. In the context of that kind of power imbalance, the free speech rights of students deserve particular deference. Unfortunately, as we know from the memory of four dead in Ohio, that deference is not always forthcoming.

Racist speech on campus occurs in a vastly different power context. Campus racism targets minority students and faculty. Minority students often come to the university at risk academically, socially, and psychologically. ${ }^{253}$ Minority faculty are typically untenured, overburdened, isolated, or even nonexistent, as is the case at several

thank my colleague Dr. Chalsa Loo, a psychologist, college counselor, and specialist in multicultural interaction, for these insights.

250. See, e.g., Wilkerson, supra note 61 (effects of racist speech at University of Michigan, including withdrawal from campus activities, obsession with racism, feelings of conspicuousness in classes, defensiveness, anger, shame, and helplessness).

251. Some minority students are avoiding white-dominated universities altogether because of apprehension of racist attacks As a member of the University of Wisconsin Board of Regents testified:

I now have a 17 year old son and he is getting ready to go off to college. Guess what? In spite of the fact that I am a member of the Board of Regents, he has no interest in attending the UW System. In fact, he has no interest in going anywhere where he will be subjected to harassment because of his color. To date, he has limited his exploration to only traditionally black schools.

Testimony of Erroll B. Davis, Jr., before the Wisconsin Senate Education Committee (Apr. 24, 1989) (unpublished comments on file with author).

252. See, e.g., Tinker v. Des Moines Indep. Community School Dist., 393 U.S. 503 (1969).

253. Applegate \& Henniger, Recruiting Minority Students: A Priority for the " 90 s, THoughT \& ACTION, Spring 1989, at 53 (minorities underrepresented in professions, declining in college enrollment, and experiencing higher drop-out rates); Crenshaw, Forward: Toward a Race-Conscious Pedagogy in Legal Education, 11 NATL. BLACK L.J. 1, 2 (1989) (the norm of "perspectivelessness" in law schools is a particular burden on minority law students); Loo \& Rolison, Alienation of Ethnic Minority Students at a Predominantly White University, 57 J. HIGHER EDUC. 58 (1986) (ethnic minority university students experience greater feelings of alienation and isolation than white students). 
law schools. ${ }^{254}$ The marginalized position of minority faculty further marginalizes minority students.

There is legal precedent for considering the status of the target in measuring the amount of freedom verbal attackers enjoy. In the law of defamation, private figures can more easily obtain damages for harm to their reputation than can public figures. This is based on the greater ability of public figures to launch an effective rebuttal and on their voluntary choice to enter the public eye. An additional implicit justification is that wealth, power, and fame provide ego support that helps one weather verbal abuse. If nothing else, the defamed movie star can retreat to Malibu.

The student, like the private figure, has fewer avenues of retreat. Living on or near campus, studying in the library, and interacting with fellow students are integral parts of university life. ${ }^{255}$ When racist propaganda appears on campus, target-group students experience debilitated access to the full university experience. This is so even when hate propaganda is directed at groups rather than individuals. ${ }^{256}$

Students are analogous to the captive audience that is afforded special first amendment consideration in other contexts. ${ }^{257}$ Similarly, students who support universities through tuition and who are encouraged to think of the university as their home are involuntarily forced into a position of complicity with racism when their campus is

254. See R. Delgado, supra note 218 (reporting on widespread effects of discrimination and high attrition rates among minority law teachers); Chused, The Hiring and Retention of Minorities and Women on American Law School Faculties, 137 U. PA. L. REV. 537 (1988); Haines, Minority Law Professors and the Myth of Sisyphus: Consciousness and Praxis Within the Special Teaching Challenges in American Law Schools, 10 NATL. BLACK L.J. 247 (1988); McGee, Symbol and Substance in the Minority Professoriat's Future, 3 HARv. BLACKLETTER J. 67 (1986) (special burdens and obligations of minority law professors).

255. See BoARd of TRUSTEEs, STANFord UNIVERSITY, FinAL REPORT ON RECENT INCIDENTS AT UJAMAA. HOUSE (1989) (describing racist incidents in a Stanford residence house and detailing the devastating emotional effect upon students of racist incidents in their residence house). These events are also discussed in Williams, supra note 10.

256. In a compromise between equality of access and first amendment claims, Stanford University proposed to regulate only hate speech directed against individuals or small groups of individuals. See Fundamental Standard, supra note 191, at 1 (including in the definition of harassment by vilification the requirement that it be "addressed directly to the individual or individuals whom it insults" and that it insults "an individual or a small number of individuals").

Los Angeles hate crime reporting guidelines require a specific target such as an individual, a home, or a place of worship. Generalized hate crimes, such as freeway graffiti, are excluded. HATE CRIME IN L.A., supra note 80, at 5-6.

In my experience, I never hear the next words after a racial slur against my group, Japanese Americans. I don't think a student can hear a racial slur on the way to a lecture, and then concentrate on the lecture as though nothing has happened. The lack of individual targeting does not guarantee a lack of individual harm.

257. FCC v. Pacifica Found., 438 U.S. 726 (1978) (limiting broadcast of obscene words to a captive audience); see also Rowan v. United States Post Office Dept., 397 U.S. 728 (1970) (control over unwanted mail allowed because of sanctity of the home). 
offered to hate groups as a forum. ${ }^{258}$

A related and literally captive group deserves mention here. The majority of prison inmates in many communities are people of color. Prisons are also fertile grounds for spreading racist hate speech. Courts have protected the rights of hate groups in prisons. ${ }^{259}$ The physical vulnerability and inability to escape that characterizes prison life make restriction of hate speech in prisons more important than in the population at large.

\section{Summary: ExPanded Relevance ANd The HaRd Cases}

[T]erse epithets come down to our generation, weighted with hatreds accumulated through centuries of bloodshed. 260

[I]f we want to be whole, we must recall the past, those parts which we want to remember, those parts which we want to forget. ${ }^{261}$

The cases discussed above are an effort to construct the conversation we might have if we take on the task of delineating and penalizing the most harmful class of racist speech. It is not an impossible conversation. It is a different one, in that it suggests a highly contextualized analysis and a range of relevant evidence quite at odds with that found in typical legal inquiry. ${ }^{262}$ This evidence encompasses the particularity of a victim's time and place as well as the experience of a victim's group over the course of time and space. ${ }^{263}$ It recognizes that the experience of racism, of persecution for membership in a group, makes the group's consciousness the victim's consciousness, all of which is relevant in assessing the harm of racist speech. ${ }^{264}$ It makes relevant,

258. Compare the case of public utilities. The state may not prohibit corporate actors from enclosing controversial messages in utility bill envelopes. Consolidated Edison v. Public Serv. Commn., 447 U.S. 530 (1980).

259. See, e.g., Note, Constitutional Analysis in the Prison Context, 44 Alb. L. Rev. 888 (1980) (discussing Curle v. Ward, 46 N.Y.2d 1049, 389 N.E.2d 1070, 416 N.Y.S.2d 549 (1979) (prison guard's right to join KKK upheld over Department of Correction's claim that AfricanAmerican inmates were terrorized by the Klan)).

260. Kunz v. New York, 340 U.S. 290, 299 (1951) (Jackson, J., dissenting).

261. B. Christian, "Somebody Forgot to Tell Somebody Something": African-American Women's Historical Novels, Paper delivered at the University of Hawaii 21 (Apr. 1989) (on file with author).

262. Beauharnais v. Illinois, 343 U.S. 250 (1952), demonstrates the Court's ability to marshal evidence of the level of racial strife in a community, and of the historical connection between racism and violence as it relates to a specific example of hate speech. It cites migration patterns, race riots, bombings, and the history of nativism and racial animosity in Chicago. 343 U.S. at 259-62.

263. Christine Littleton identifies contextuality in critical legal studies analysis: "[S]eparating the individual from her or his social context in litigation leaves out of a case the very elements that make the case necessary in the first place - unequal social power." Littleton, supra note 31 , at 760 .

264. Justice Blackmun, in his dissent to the denial of certiorari in the Skokie case, suggested the possible continued applicability of Beauharnais, and quoted from Schenck, "the character of 
then, knowledge as old as the Torah and as new as the back page of this morning's newspaper. It makes relevant, too, what has happened to you, to me, to an acquaintance, to a friend of a friend, to a person whom we have never met but who is tied to us as a survivor of the same hate.

This deep historical consciousness lifts us out of the neutrality trap, that trap under which many states have passed anti-mask statutes in a barely disguised effort to limit Ku Klux Klan activities.265 These statutes purportedly cover the wearing of masks in general, with no specific mention of the intent to control the Klan. Neutral reasons, such as the need to prevent pickpockets from moving unidentified through crowds, or the need to demask burglars and bank robbers, are proffered for such statutes. ${ }^{266}$ The result of forgetting - or pretending to forget - the real reason for antimask legislation is farcical. Masks are used in protest against terrorist regimes, for reasons of both symbolism and personal safety. Iranian students wearing masks and opposing human rights violations by the Shah of Iran, for example, were prosecuted under a California antimask statute. ${ }^{267}$

This Article calls for an end of such unknowing. We know why state legislatures - those quirkily populist institutions - have passed anti-mask statutes. It is more honest, and less cynically manipulative of legal doctrine, to legislate openly against the worst forms of racist speech, allowing ourselves to know what we know.

\section{The Unintended Story: The Meaning of Legal Protection of Racist Hate Messages}

The legal response to racist propaganda provides an interesting context for examination of the relation between law and racism. Legal protection of racism is seen in these doctrinal elements:

every act depends upon the circumstances in which it is done." Smith v. Collin, 439 U.S. 416, 419 (1978) (Blackmun, J., dissenting) (quoting from Schenck v. United States, 249 U.S. 47, 52 (1919)).

265. See Johnson, Can the State Unmask the Clan?, KY. BENCH \& BAR, Apr. 1981, at 8 (citing statutes in California, Michigan, Kentucky, North Carolina, Alabama, Florida, South Carolina, Tennessee, Virginia, Oklahoma, and Louisiana. Some statutes contain useful exemptions for Halloween, Mardi Gras, and Gasparilla).

The Village of Skokie's ban against parading in military uniforms was another failed attempt at neutrality. Everyone knew that the feared uniform was the Nazi storm trooper uniform. The courts easily attacked the overbreadth of the "no uniforms" rule. See Village of Skokie v. National Socialist Party, 51 Ill. App. 3d 279, 366 N.E.2d 347, 354 (1977), modified on other grounds, 69 Ill. 2d 605, 373 N.E.2d 21 (1978).

266. Johnson, supra note 265 (citing City of Pineville v. Marshall, 222 Ky. 4, 299 S.W. 1072, 1073 (1927) (fear of pickpockets and bandits justified use of police power to ban masks)).

267. See Ghafari v. Municipal Court, 87 Cal. App. 3d 255, 150 Cal. Rptr. 813 (1978) (overturning, on first amendment grounds, convictions for protesting while wearing masks). 
(1) the limits of doctrinal imagination in creating first amendment exceptions for racist hate speech;

(2) the refusal to recognize the competing values of liberty and equality at stake in the case of hate speech; and

(3) the refusal to view the protection of racist speech as a form of state action.

The limits of lawmaking imagination of judges, legislators, and other legal insiders who have considered proposals to outlaw hate propaganda is symptomatic of Derrick Bell's interest convergence theory. ${ }^{268}$ This limitation of imagination is a disability, a blindness, that prevents lawmakers from seeing that racist speech is a serious threat. Legal insiders cannot imagine a life disabled in a significant way by hate propaganda.

This limited imagination has not affected lawmakers faced with other forms of offensive speech. Laws against dissemination of child pornography and the law of defamation and privacy are examples of areas in which the law recognizes that certain forms of expression are qualitatively different from the kind of speech deserving absolute protection. ${ }^{269}$ The legal imagination is able to contemplate what it feels like to hear lies spread about one's professional competency, ${ }^{270}$ to have one's likeness used for commercial gain without consent, ${ }^{271}$ or to hear unwanted obscenities on the radio. ${ }^{272}$ American law has even, at times, provided a tort remedy for white plaintiffs who are "insulted" by "imputation of association with persons of a race to which there is prejudice."273 When the legal mind understands that reputational interests, which are analogized to the preferred interest in property,

268. D. Bell, RACE, RACISM, AND AMERICAN LAW (2d ed. 1980) (arguing that reform on race issues occurs only when it serves majority interests). As one Atlanta official put it, "If blacks and Jews and other minorities were similarly organized for harassment of and violence to whites, the nation would be turning upside down." Opening Comments of Ms. Jan Douglas, Director, Community Relations Commission, City of Atlanta, at the Open Meeting on Racial and Religious Bigotry and Violence, Atlanta, Ga., Sept. 24, 1981, quoted in HATE Group ACTIVITY, supra note 61 , at 1 .

269. See Young v. American Mini Theatres, Inc., 427 U.S. 50 (1976); New York v. Ferber, 458 U.S. 747 (1982). Professor Frederick Schauer argues that the Ferber case is an example of the emerging willingness of the Supreme Court to devise different first amendment constructs for different categories of speech. See Schauer, Codifying the First Amendment: New York v. Ferber, 1982 Sup. Cr. REV. 285; see also Sunstein, supra note 66 (arguing for a distinction between low value and high value speech).

270. See W. Prosser, HaNdBook of THE LAW OF TORTS 737 (4th ed. 1971) (stating that "there is a great deal of the law of defamation which makes no sense," and going on to describe the action of defamation).

271. This concept was first imagined by Warren and Brandeis in their article The Right to Privacy, 4 HARV. L. REV. 193 (1890).

272. See FCC v. Pacifica Found., 438 U.S. 726 (1978).

273. Annotation, Libel and Slander: Imputation of Association with Persons of Race or Nationality as to Which There Is Social Prejudice, 121 A.L.R. 1151, 1151 (1939) (citing Sharp v. Bussey, 137 Fla. 96, 187 So. 779 (1939)). 
must be balanced against first amendment interests, it recognizes the concrete reality of what happens to people who are defamed. Their lives are changed. Their standing in the community, their opportunities, their self-worth, their free enjoyment of life is limited. To see this, and yet to fail to see that the very same things happen to the victims of racist speech, is selective vision.

The selective consideration of one victim's story and not another's results in unequal application of the law. Unlike the victims of defamation and other torts, the victims of racist speech are not representative of the population at large. In making typical legal concessions to the first amendment, we burden a range of victims. In the case of flagburning, we force patriots, veterans, and flag-lovers of all races to tolerate flag desecration as part of the price of freedom. In contrast, when victims of racist speech are left to assuage their own wounds, we burden a limited class: the traditional victims of discrimination. This class already experiences diminished access to private remedies such as effective counterspeech, and this diminished access is exacerbated by hate messages. Debasing speech discredits targets, further reducing their ability to have their speech taken seriously. ${ }^{274}$ The application of absolutist free speech principles to hate speech, then, is a choice to burden one group with a disproportionate share of the costs of speech promotion. ${ }^{275}$ The principle of equality is violated by such allocation. ${ }^{276}$ The more progressive principle of rectification or reparation $^{277}$ - the obligation to repair effects of historical wrongs - is even more grossly violated.

The failure to hear the victim's story results in an inability to give weight to competing values of constitutional dimension. ${ }^{278}$ The com-

274. Professor Catharine MacKinnon argues, similarly, that pornography causes women to be taken less seriously as they enter the public arena. MacKinnon, Not A Moral Issue, YALE L. \& Poly. REV., Spring 1984, at 321; see also Sunstein, supra note 66, at 619 (analogizing the case for antipornography legislation to footnote four in United States v. Carolene Prods., 304 U.S. 144, 152 n.4 (1938), and recognizing "maldistribution of private power").

275. Tolerance of hate speech thus creates super-regressivity - those least able to pay are the only ones taxed for tolerance. Note that it is even more regressive than the typical sales tax, under which an equal percentage is applied to unequal payers. Under that system no one group is exclusively taxed. See also Marcuse, Repressive Tolerance, in A CRITIQUE OF PURE TOLERANCE 81 (1969); Cf. Kornhauser, The Rhetoric of the Anti-Progressive Income Tax Movement: $A$ Typical Male Reaction, $86 \mathrm{MiCH}$. L. REV. 465 (1988) (history and normative evaluation of regressive and progressive schemes of taxation in the United States).

276. This contextualized understanding of equality is admittedly at odds with the conservative view of equality as equal treatment without regard to individual disadvantage. See, c.g., Washburn, Liberalism versus Free Speech. NATL. REV., Sept. 30, 1988, at 39 (comparing an African-American professor's complaints of harassment unfavorably to historical examples of toleration of insults generated by whites against whites).

277. See Matsuda, supra note 20.

278. As Detroit City Councilperson Mel Ravitz said in explanation of his support for a denial of a park-use permit to the SS Action Group: 
peting values recognized under international law are equality, liberty, and personality. Each person under that scheme is entitled to basic dignity, to nondiscrimination, and to the freedom to participate fully in society. ${ }^{279}$ If there is any central principle to the Bill of Rights, surely that is it. When white supremacist organizations with histories of violence have an active, protected presence in a community, that principle is sacrificed. All our democratic institutions are tainted as a consequence. ${ }^{280}$ As Professor Delgado has noted, the underlying first amendment values of self-fulfillment, knowledge, participation, and stable community recognized by first amendment theorists are sacrificed when hate speech is protected.281 The constitutional commitment to equality and the promise to abolish the badges and incidents of slavery are emptied of meaning ${ }^{282}$ when target-group members must alter their behavior, change their choice of neighborhood, leave their jobs, and warn their children off the streets because of hate group activity. When the presence of the Klan deters employers from hiring target-group members, prevents citizens from socializing freely, and keeps parents from sending their children to integrated schools, the

In addition to honoring the rights guaranteed under the First Amendment, it is also the City Council's obligation to honor the rights guaranteed by the Thirteenth, Fourteenth, and Fifteenth Amendments of the same Constitution. Those Amendments are the constitutional basis for "equality," which is as much a fundamental constitutional right as freedom of speech.

National Alliance Against Racist \& Political Repression, Now Is the Time: Outlaw the KKK, Nazis, and Other Hate Groups, ORGANIZER, June/July 1986, at 2, 7.

279. Fanny Drake Crumsey of Chattanooga, Tennessee, the victim of a random Klan shooting spree on April 19, 1980, expressed the claim to personhood succinctly:

I think that I have the right and the privilege to sit on my porch, plant flowers in my yard, and visit my neighbors freely, without any physical or mental abuse. That includes not being shot at, shot, or any other form of danger to me, a peaceful law-abiding citizen of this and any other community.

SOUTHERN ORganizing CoMmitTeE \& SOUTHERN Christian LEADERSHIP CONFERENCE, Challenge to America: Victims of Racist Violence Tell Their Stories 3 (1981).

For a classic discussion of the denial of personhood engendered by a racist environment, see W.E.B. DuBoIs, supra note 25.

280. The jury system, for example, is suspect when racist speech enters jury deliberations. See Note, Racist Slurs by Jurors as Ground for Impeaching a Jury's Verdict: State v. Shillcut, 1985 WIS. L. REv. 1481 (In State v. Shillcut, 119 Wis. 2d 788, 350 N.W.2d 686 (1984) the court denied a new trial in spite of a juror's comment to the effect that the defendant was AfricanAmerican and therefore probably guilty.).

281. Delgado, supra note 6; see also supra text accompanying note 54. Self-fulfillment is sacrificed when racial insults are internalized by victims and perpetrators - both groups are denied the ability to choose to live in harmony.

282. See Jones, supra note 22, at 433-34; Professor Charles Lawrence has argued that Brown v. Board of Education was really about racist speech. Segregation was wrong, the Court found, because of the message of inferiority communicated by segregation. The Court in Brown limited the expression of an idea. See Beyers, Lawyers Debate lst Amendment Limits, Interpretation of Fundamental Standard, Stanford University Campus Report, Apr. 12, 1989, at 1, col. 1, at 6, col. 1 (quoting Charles Lawrence); see also Lawrence, "One More River to Cross"-Recognizing the Real Injury in Brown: A Prerequisite to Shaping New Remedies, in SHADES OF BROWN: NEW Perspectives on School Desegregation 48 (D. Bell ed. 1980). 
goal of nondiscrimination is moved farther away from present realities. When hate propaganda spreads attitudes of racism and desensitizes potential abusers to the wrongness of violence, other more obvious goals of safety and order are sacrificed.

The third doctrinal pillar supporting racist speech is the refusal to recognize that tolerance and protection of hate group activities by the government is a form of state action. To allow an organization known for violence, persecution, race hatred, and commitment to racial supremacy to exist openly, and to provide police protection and access to public streets and college campuses for such a group, means that the state is promoting racist speech. If not for such support, hate groups would decline in efficacy. The chilling sight of avowed racists in threatening regalia marching through our neighborhoods with full police protection is a statement of state authorization. ${ }^{283}$ The Klan marches because marching promotes the Klan, and because of the terrorizing and inciting effect of its public displays. Open display conveys legitimacy. The government advances this effect when it protects these marches. In addition, the failure to provide a legal response limiting hate propaganda elevates liberty interests of racists over liberty interests of targets. A member of the Georgia Bureau of Investigation, for example, once suggested to whites targeted for hate speech because of their association with African Americans that they should avoid being seen in cars with African Americans, and cease inviting African Americans to their homes. ${ }^{284}$

The effect of racist propaganda is to devalue the individual and to treat masses of people in a degraded way with no measure of individual merit. This is precisely what civil libertarians oppose when the state acts. ${ }^{285}$ Because racist speech is seen as private, the connection to loss of liberty is not made. State silence, however, is public action where the strength of the new racist groups derives from their offering legitimation and justification for otherwise socially unacceptable emotions of hate, fear, and aggression. ${ }^{286}$ The need for a formal group, for

283. In fact, the historical connection between hate groups and the state is more than passive; law enforcement officers have been active as well as passive participants in groups like the KKK. See P. Sims, supra note 1, at 245-48 (deputy sherriff convicted in killing of three civil rights workers in Mississippi).

284. HATE GROuP ACTIVITY, supra note 61, at 21.

285. See, e.g., Jacobs \& Strossen, Mass Investigations Without Individualized Suspicion: A Constitutional and Policy Critique of Drunk Driving Roadblocks, 18 U.C. DAVIS L. REV. 595 (1985). The Klan has also raised objections to generalized searches. See Wilkinson v. Forst, 591 F. Supp. 403 (D. Conn. 1984) (KKK challenges generalized weapons search of attendees at KKK rallies).

286. See H. KITANo, supra note 68, at 113 (discussion of displaced aggression and racial discrimination). See generally D. BennetT, The Party of Fear: From Nativist Move- 
a patriotic cause, and for an elevation of the doubting self are part of the traditional attraction of groups like the Klan. Government protection of the right of the Klan to exist publicly and to spread a racist message promotes the role of the Klan as a legitimizer of racism. ${ }^{287}$

Further, the law's failure to provide recourse to persons who are demeaned by the hate messages is an effective second injury to that person. ${ }^{288}$ The second injury is the pain of knowing that the government provides no remedy, and offers no recognition of the dehumanizing experience that victims of hate propaganda are subjected to. ${ }^{289}$ The government's denial of personhood by denying legal recourse may be even more painful than the initial act of hatred. One can dismiss the hate group as an organization of marginal people, but the state is the official embodiment of the society we live in.

The legal realists and their progeny recognize that law formation is largely a matter of value. ${ }^{290}$ There are no inevitable results; there is no controlling logic or doctrine that can make the hard choices for us. Reversion to discredited doctrinal absolutism carries a strong implication that racist activities are supported, albeit unintentionally, by the law. In a society that expresses its moral judgments through the law, and in which the rule of law and the use of law are characteristic responses to many social phenomena, this absence of laws against racist speech is telling.

We can defy the proposition that racism is part of law by opening our eyes to the reality of racism and making the decision to outlaw hate groups. We can draw from the international standard and acknowledge the competing interests at stake, adapting existing law and creating new law to limit hate group activities. It is not necessary to abandon first amendment values in order to do this. The analytical

MENTS TO THE NEW RIGHT IN AMERICAN HISTORY (1988) (historical fear of sinister enemies as impetus for racist movements).

287. Racist organizations are also eligible for attorneys' fees when they challenge government limitations of racist speech. Targets are thus further taxed for exercise of Klan speech. See, e.g., Knights of the Ku Klux Klan v. East Baton Rouge Parish School Bd., 735 F.2d 895 (5th Cir. 1984) (upholding award of attorneys' fees where KKK challenged the board's denial of school facilities to racist groups).

288. Cf. R. NADER, UNSAFE AT ANY SPEed 81-146 (1965) (discussing the second injury caused when accident victims strike the interior of their own cars). As Professor David Kretzmer has argued, "a society committed to ideals of social and political equality cannot remain passive: it must issue unequivocal expressions of solidarity with vulnerable minority groups and make positive statements affirming its commitments to those ideals." Kretzmer, supra note 36 , at 456 .

289. See Delgado, supra note 6.

290. Llewellyn, Some Realism About Realism - Responding to Dean Pound, 44 Harv. L. REV. 1222, 1236 (1931) ("The conception of law as a means to social ends and not an end in itself"). 
dexterity of legal thinkers offers many options for reconciling the American position with the international goal of elimination of all forms of racial discrimination.

Professor Massaro in her contribution to this symposium challenges us to choose among stories, among values. This Article suggests that the stories of those who have experienced racism are of special value in defeating racism. It further suggests that we can, and have, chosen as a primary value freedom from racial oppression. Finally, in doing the awkward work of constructing doctrine, this Article suggests a belief in the possibility and the necessity of creating a legal response to racist speech that transcends first amendment absolutism. We can attack racist speech - not because it isn't really speech, not because it falls within a hoped-for neutral exception, but because it is wrong.

There is, in every constitutional doctrine we devise, the danger of misuse. For fear of falling, we are warned against taking a first step. Frozen at the first amendment bulkhead we watch the rising tide of racial hatred wash over our schools and work places. Students victimized by racist speech turn to university administrations for redress, and are told that the first amendment forecloses institutional action. We owe those students a more thoughtful analysis than absolutism. At the least, before we abandon the task of devising a legal response to racist speech, we should consider concretely the options available to us. The legal imagination is a fruitful one. That is the one hopeful message of the postmodern critique of law. Nothing inherent in law ties our hands, and lawyers, through the ages, have displayed abundant skills of invention.

\section{CONCLUSION}

The emerging jurisprudence of outsiders uses the experience of subordination to offer a phenomenology of race and law. The victims' experience reminds us that the harm of racist hate messages is a real harm, to real people. When the legal system offers no redress for that real harm, it perpetuates racism.

This Article attempts to begin a conversation about the first amendment that acknowledges both the civil libertarian's fear of tyranny and the victims' experience of loss of liberty in a society that tolerates racist speech. It suggests criminalization of a narrow, explicitly defined class of racist hate speech, to provide public redress for the most serious harm, while leaving many forms of racist speech to private remedies. Some may feel this proposal does not go far enough, leaving much hurtful speech to the uneven control of the marketplace 
of ideas. Others will cringe at what they perceive as a call for censorship. This is not an easy legal or moral puzzle, but it is precisely in these places where we feel conflicting tugs at heart and mind that we have the most work to do and the most knowledge to gain.

We are a legalized culture. If law is where racism is, then law is where we must confront it. The doctrinal reconstruction presented here is tentative and subject to change as our struggle around this issue continues. However we choose to respond to racist speech, let us present a competing ideology, one that has existed in tension with racism since the birth of our nation: there is inherent worth in each human being, and each is entitled to a life of dignity. 